\title{
Mid-late Cenomanian larger benthic foraminifers from the El Abra Formation W Valles-San Luis Potosi Platform, central-eastern Mexico: Taxonomy, biostratigraphy and paleoenvironmental implications
}

Lourdes Omaña, Rubén López-Doncel, José Ramón Torres, Gloria Alencaster, Iriliana López-Caballero

Lourdes Omaña

\section{Gloria Alencaster}

lomanya@geología.unam.mx

Departamento de Paleontologia, Instituto de Geologia, Universidad Nacional Autonoma de Mexico, Ciudad Universitaria, Coyoacan, 04510, CDMX, Mexico.

Rubén López-Doncel

José Ramón Torres

Instituto de Geologia, Universidad Autonoma de San Luis Potosi, Av. Dr. Nava \# 5, San Luis Potosi, Mexico.

Iriliana López-Gaballero

Facultad de Ciencias, Universidad Nacional Autonoma de Mexico, Ciudad Universitaria, Coyoacan, 04510, CDMX, Mexico.

BOL. SOC. GEOL. MEX. 2019

VOL. 71 NO. 3

P. $691-725$

http://dx.doi.org/10.18268/BSGM2019v71n3a5

\begin{abstract}
The Valles-San Luis Potosí Platform is part of an extensive carbonate platform system that rimmed the ancestral Gulf of Mexico during the middle (Albian) through Upper Cretaceous. The El Abra Formation consists of a shallow-water deposit; it contains a benthic foraminiferal assemblage that includes 18 species, which are described and illustrated in this paper. The studied successions from the upper part of the El Abra Formation were dated as mid-late Cenomanian. On the basis of these findings, two zones are proposed Pseudolituonella reicheli Assemblage Zone and Nezzazatinella picardi Interval Zone. The first Assemblage Zone is characterized by an abundant benthic foraminiferal association. It is overlain by the Nezzazatinella picardi Interval Zone where the species richness of the foraminiferal assemblage is reduced and later disappears. The benthic foraminiferal demise is coincident with major sea-level changes and an increase in siliciclastic input from the hemipelagic deposit of the Soyatal Formation, which contains abundant pithonellids and $r$ and $r-k$ strategist planktic foraminifera (Whiteinella archaeocretacea Partial Range Zone). Two stratigraphically correlative facies have been recognized in the El Abra Formation: the Taninul and the El Abra Facies. A warm, shallow-water, open marine platform deposit (Taninul Facies) is inferred. It includes peloidal-foraminiferal packstone, packstone-grainstone, and packstonewackestone. A restricted environment (El Abra Facies) can be deduced from the abundant miliolids and ostreids. The texture is a wackestone-packstone. Another microfacies (Soyatal Formation) consists of wackestone-packstone with an acme of pithonellids and the occurrence of $r$ and $r-k$ strategist planktic foraminifers deposited during the platform drowning.
\end{abstract}

Keywords: Cenomanian, benthic foraminifers, El Abra Formation, San Luis Potosí, Mexico.

\section{RESUMEN}

La Plataforma Valles-San Luis Potosí es parte de un sistema de plataformas extenso que se encontraba bordeando el antiguo Golfo de México en el Albiano hasta el Cretácico Superior. La caliza El Abra es un depósito de aguas poco profundas; ésta contiene un conjunto de foraminiferos bentónicos que incluye 18 especies, que se describen e ilustran en este documento. Las sucesiones estudiadas de la parte superior de la Formación de El Abra fueron datadas como del Cenomaniano mediotardio; se proponen dos zonas (Zona de Conjunto Pseudolituonella reicheli y Zona de Intervalo Nezzazatinella picardi). La primera Zona de Conjunto se caracteriza por una asociación abundante de foraminiferos bentónicos. Está sobreyacida por la Zona de Intervalo Nezzazatinella picardi donde se reduce la riqueza de especies de las asociaciones de foraminiferos y luego desaparece. La desaparición de foraminiferos bentónicos es coincidente con grandes cambios de nivel del mar y un aumento en el aporte de sedimentos desde el depósito hemipelágico de la Formación Soyatal que contiene abundantes pithonélidos y foraminiferos planctónicos de estrategía $r$ y $r$-k (Zona de Alcance Parcial (Whiteinella archaeocretacea)). Dos facies estratigráficamente correlacionables han sidoreconocidas en la Formación El Abra: la Facies Taninul y la Facies El Abra. Se infiere un depósito de plataforma marina abierta de aguas cálidas someras (Facies Taninul). Ésta incluye un packstone peloidal con foraminiferos, packstone y packstone-wackestone. Un ambiente restringido (Facies El Abra) puede deducirse por los abundantes miliólidos y ostreídos. La textura de la roca es un wackestone-packstone. Otra microfacies consiste de un wackestonepackstone con un auge de pithonélidos y la presencia de foraminiferos de estrategia $r$ y $r$ - $k$ depositados durante la inundación de la plataforma (Formación Soyatal).

Palabras clave: Cenomaniano, foraminíferos bentónicos, Formación El Abra, San Luis Potosí, México. 


\section{Introduction}

During the mid-Cretaceous, particularly in the Albian through Cenomanian, widespread carbonate platform development took place throughout the tropical-subtropical shallow-water environments of the Tethys (Schroeder and Neumann, 1985, p. 5). Benthic foraminifers and algae are the most important groups that inhabited this milieu. In Mexico, during the Albian/Cenomanian, the Valles-San Luis Potosí Platform (VSLPP) was part of a wide carbonate platform system that bordered the ancestral Gulf of Mexico (Salvador, 1991). This platform experienced the evolution of a rich and diverse benthic foraminiferal assemblage now contained in the El Abra Limestone.

In this study, we analyzed calcareous samples derived from the Cenomanian El Abra Formation containing an abundant and well-preserved benthic foraminiferal assemblage that also includes algae, corals, echinoderms, and annelids.

The El Abra Formation is renowned for its invertebrate fossils, primarily Albian rudists, which have been analyzed by numerous authors (e.g. Adkins, 1930; Coogan; 1973; Alencáster, 1998; Alencáster and García-Barrera, 2008).

The Albian benthic foraminifers from the El Abra Formation were documented by Bonet (1956), and Tavitas and Solano (1984) from the eastern part VSLPP. They reported an assemblage composed of Orbitolina (Mesorbitolina) texana, Dictyoconus walnutensis (Carsey), Coskinolina sunnilandensis (Maync), Pseudonummoloculina heimi (Bonet), and Dicyclina schlumbergeri (Munier-Chalmas).

We studied the benthic foraminiferal community from the western part of the VSLPP. This association has been dated as middle-late Cenomanian and is very different from the well-known foraminiferal association of the eastern part composed mostly of orbitolinids (Omaña et al., 2016).

The upper part of the El Abra Formation in the area of study represents the last shallow-water deposit preceding the VSLPP, which was drowning at the Cenomanian/Turonian boundary interval (Basañez et al., 1993; Omaña et al., 2012). It is overlain by a succession of bioclastic packstone and pelagic wackestone bearing planktic foraminifers and pithonellids (Soyatal Formation).

The drowned episode in the Cenomanian/Turonian $(\mathrm{C} / \mathrm{T})$ interval at the global level is linked with rising sea level (Haq et al., 1987; Haq, 2014; Hallam, 1992; Miller et al., 2005; Gale et al., 2008), and widespread flooding of Mediterranean platforms (Drzewiecki and Simó, 1977; Caus et al., 1997; Hart et al., 2005; El-Sabbagh et al., 2011; Korbar et al., 2012).

The start of the demise of the carbonate platforms occurred during the latest Cenomanian (Whiteinella archaeocretacea Zone), with a major biological change that affected benthic organisms such as rudists and larger benthic foraminifera.

Philip and Airaud-Crumière (1991, p. 117) documented that the benthic foraminifera were affected in two steps; the genera Praealveolina, Chrysalidina, Pseudocyclammina, and Pseudolituonella disappeared at the top of Geslinianum Zone. During the late Cenomanian (fuddii Zone) the benthic forami nifera were scarce and poorly diversified miliolids, textularids, and trochamminids. At second step occurs when a major extinction affected the benthic foraminifera at the $\mathrm{G} / \mathrm{T}$ boundary.

Parente et al. (2008) also reported a two-step pa ttern of extinction of larger foraminifers in the upper Cenomanian in shallow-water carbonates of the southern Apennines (Italy). They stated that "the first step eliminated the alveolinids, the most extreme $k$ strategists, reducing the diversity of the larger foraminifera to less complex forms such as Chrysalidina, Pseudolituonella and Pseudoraphydionina; when the high productivity persisted only $r$-opportunist planktic foraminifers predominated while the rise of the mesotrophic threshold triggered the second step extinction of larger foraminifera."

However, in the present study, the $\mathrm{C} / \mathrm{T}$ boundary interval is characterized by the disappearance first of larger forms such as Pseudolituonella, Daxia, Merlingina, Hemicyclammina, Dicyclina, and Cuneolina. Later, only forms such as Nezzazatinella picardi, Praechrysalidina, rotalids, miliolids, and algae remained, this interval is overlain by a deposit with abundant pithonellids, and $r$ and $r-k$ strategist planktic fora- 


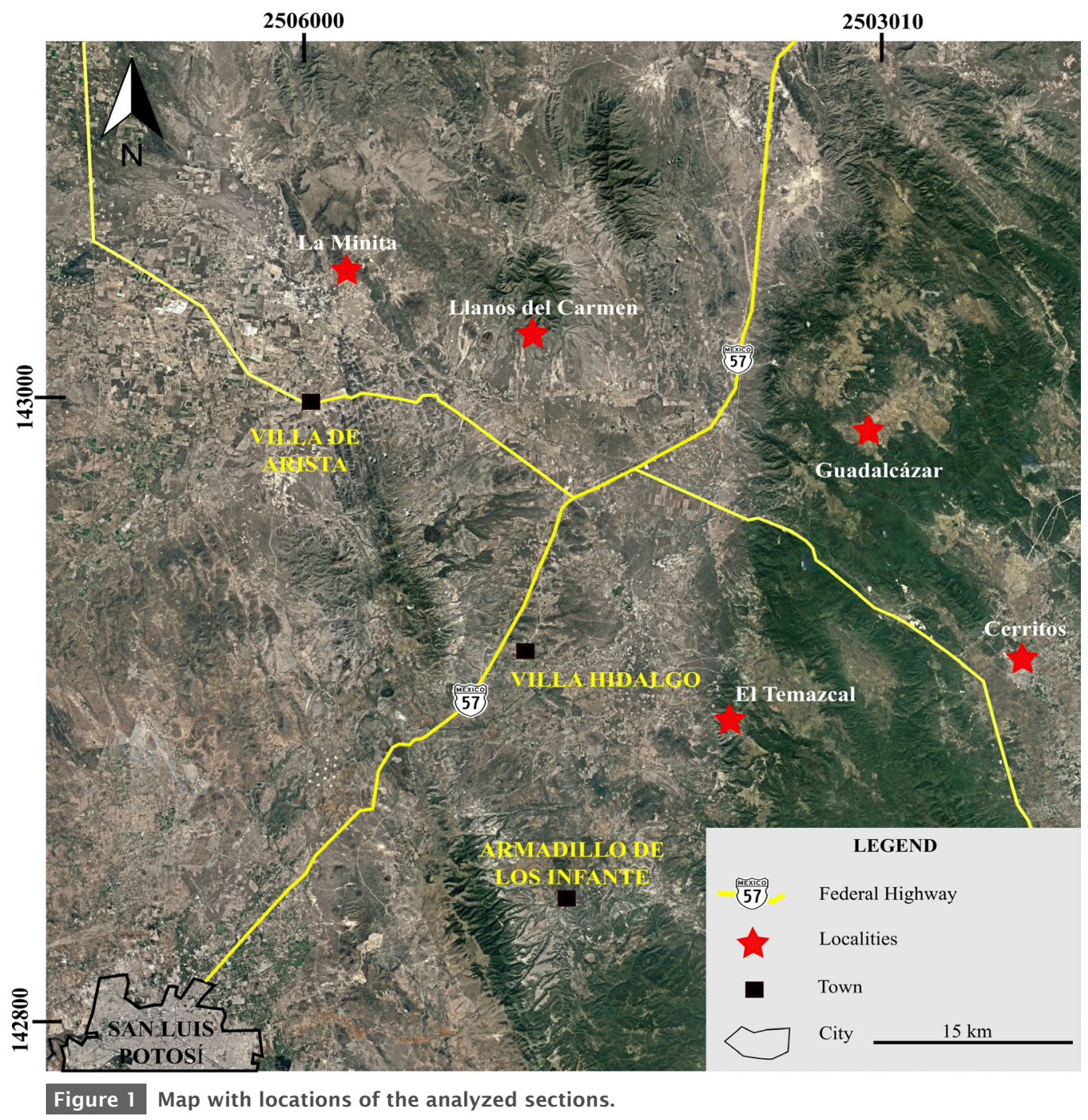

minifers with simple morphologies, such as Hedbergella, Heterohelix, Globigerinelloides, and Whiteinella as a result of flooding of the platform.

The objectives of the work are a) to describe and illustrate the benthic foraminifers identified from the upper part of the El Abra Formation as a contribution to the knowledge of the faunal assemblage of this unit in Mexico and of the western part of the Tethys Realm; b) to provide information about the distribution of the larger foraminifers before their demise, caused by the flooding of the VSLPP; c) to constrain the age of the El Abra Formation using the stratigraphic value of the benthic foraminifers, comparing the biostratigraphic standards based on them in the
peri-Tethyan area; moreover, supporting it from the planktic age of the overlying unit; and d) to integrate the paleoecological data of the larger foraminifers and the microfacies study to infer information about the paleoenvironment.

\section{Geological setting}

The samples were collected east of the city of San Luis Potosí (Figure 1). This area belongs to the western part of the VSLPP, which formed in association with the opening of the Gulf of Mexico. According to Salvador (1991), the Early Cretaceous was a time of significant tectonic stability in the Gulf of Mexico Basin. During this period, 
the influx of terrigenous sediment decreased and the stable shelves, ramps, and platforms bordering the deep central part of the basin became the site of widespread carbonate deposition, particularly during the Albian, when carbonate deposition extended from the Bahamas along the northern rim of the Gulf, across Mexico to the Yucatan Peninsula, and to various Caribbean localities (Scott, 1990). Along the western flank of the basin in east-central Mexico, carbonate platforms were more locally restricted, such as the VSLPP (Figure 2), which remained active until the Cenomanian. Wilson and Ward (1993, p. 42) stated that the VSLPP is one of "the largest isolated carbonate platforms (200 by $300 \mathrm{~km}$ ) located on the western side of the Gulf of Mexico. It initiated in the Early Cretaceous, but reached its maximum area in the Albian, when it evolved a rimmed shelf margin. The platform apparently formed along the southwestern flank of a north-northwest-trending tectonic ridge of Precambrian gneiss and Upper Paleozoic schist that is exposed at Miquihuana, 70 $\mathrm{km}$ southwest of Ciudad Victoria on the state line between Nuevo León and Tamaulipas".

Recently, Venegas-Rodríguez et al. (2009) stated that the VSLPP overlies Toarcian rocks dated by detrital zircon from the El Alamito locality at W Río Verde, San Luis Potosí. It is interpreted by these authors as a deposit from the paleo-Pacific margin occuring at same time as the opening of the Gulf of Mexico.

The VSLPP now lies within the Sierra Madre Oriental fold-thrust belt (Suter, 1984; 1987). Its eastern shelf margin is exposed in quarries along the Cuesta de El Abra near Valles and Antiguo Morelos (km 541-546 of the San Luis PotosíTampico railway). Part of its western side can be seen along road cuts $30 \mathrm{~km}$ east of the city of San Luis Potosí. The stratigraphic framework for the VSLPP has been described by Cserna and Bello-Barradas (1963), Carrillo-Bravo (1971), Suter (1990), Basañez (1993), Wilson and Ward (1993), and Torres-Hernández (1994). The depositional process has been recorded by Enos and Stephens (1993), Aguayo (1998), and López-Doncel (2003).

\section{Materials and Methods}

The studied material comes from the upper part of the El Abra Limestone (Figure 2). It was collected from four sections that ranged from 40 to $100 \mathrm{~m}$ thick located at the western part of the VSLPP: Llano del Carmen (LLC), Guadalcázar $(\mathrm{G})$, Cerritos $(\mathrm{G})$, El Temazcal (ET), as well as in the La Minita outcrop (LM).

The samples were collected at an average interval of 5 to $10 \mathrm{~m}$. The 150 thin sections were prepared both parallel and perpendicular to the stratification for foraminiferal and microfacies examination. The faunal preservation is good, which permitted precise identification; the biostratigraphic scheme is based on the benthic and planktic foraminiferal stratigraphic ranges. In addition, a microfacies study was carried out to reconstruct the paleoenvironment.

\section{Results and Discussion}

\subsection{LITHOFAGIES AND MICROFAGIES}

The El Abra Formation displays two facies, the Taninul and El Abra, which are stratigraphically correlated (Aguayo, 1998). The Taninul facies is a thick to massive skeletal bioclastic limestone mostly composed of rudists, foraminifers and algae (Figure 3a to 3c). The El Abra facies is a light gray limestone rich in miliolids and ostreids (Figure 3e and 3f).

\subsubsection{THE TANINUL FACIES}

The following sections were measured, sampled, and described from the Taninul facies.

\subsubsection{LLANO DEL CARMEN SECTION (LLC)}

The Llano del Carmen section (LLG) currently crops out north of the city of San Luis Potosí (coordinates $22^{\circ} 45^{\prime} \mathrm{N}, 100^{\circ} 40^{\prime} \mathrm{W}$ ). It consists of massive dark-gray limestone of the El Abra Formation and is $\sim 100 \mathrm{~m}$ thick (Figure 4 ). 

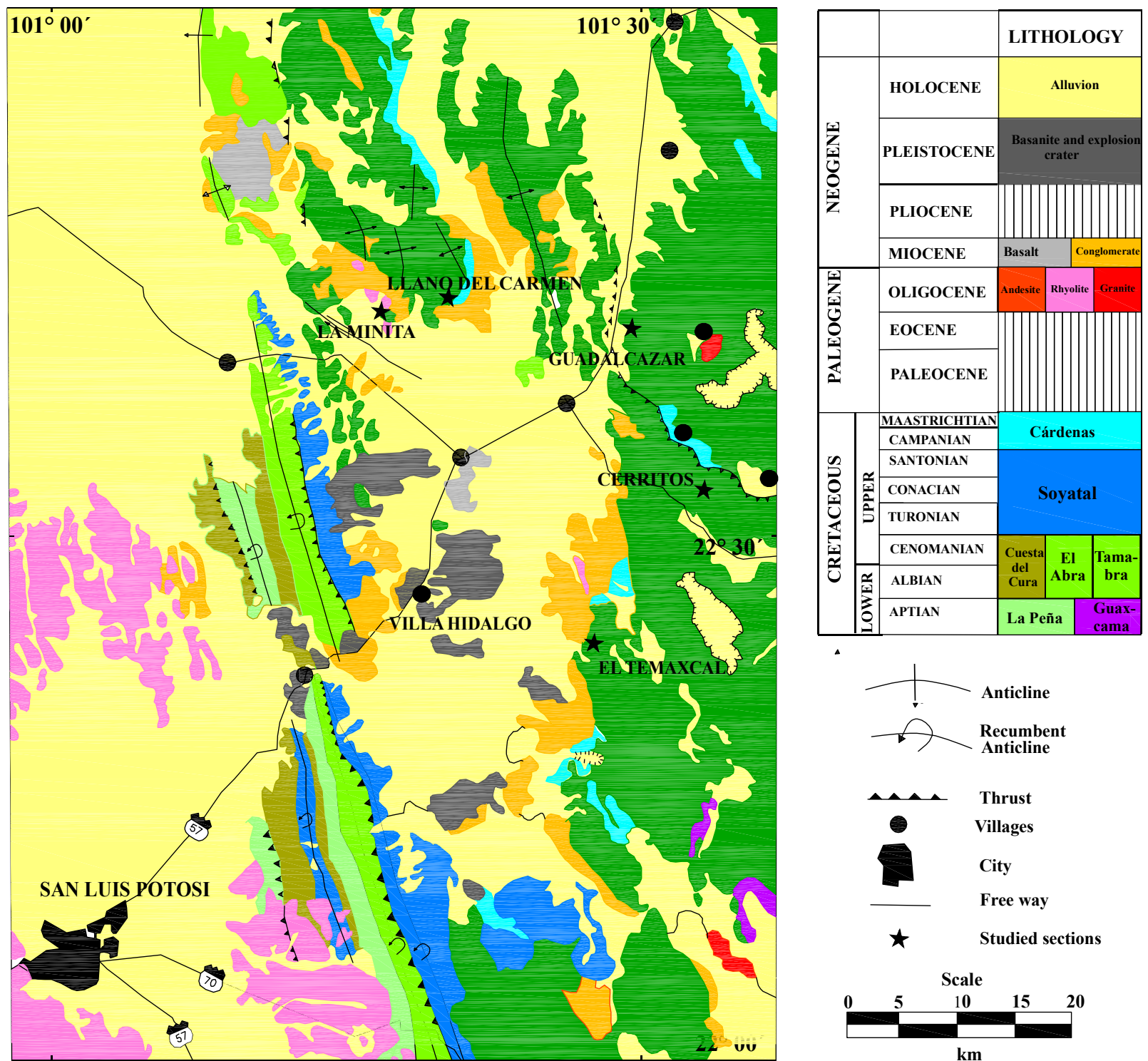

Figure 2 Geological map showing the El Abra and Soyatal Formations (modified from Labarthe et al., 1982; López-Doncel, 2003).

The petrographic analysis indicates a peloidal packstone-grainstone with high foraminiferal species richness that includes Pseudolituonella reicheli, Daxia cenomana, Hemicyclammina sigali, Merlingina cretacea, Pseudocyclammina sp., Dicyclina schlumbergeri, Cuneolina pavonia, Cuneolina parva, Nezzazata gyra, $\mathcal{N}$. simplex, Nezzazatinella picardi, Spiroloculina cenomana, Peneroplis parvus, and Minouxia inflata. The algae Bouenia sp. and encrusting Lithocodium aggregatum are present. The components of more than $60 \%$ of the content can be recognized. They are embedded in microsparitic cement, densely packed in a matrix-supported fabric. Most of the components are coated with micrite, suggesting moderate transport into a relatively high-energy environment. The lithology and faunal-algal assemblage indicates a deposit in a normal-marine open platform not subjected to significant restriction in water circulation. It is important to note that rudist Hippurites resectus is also found in this association.

Other microfacies consist of a coated, poorly sorted foraminiferal grainstone consisting of miliolids and other forms such as Peneroplis parvus, 

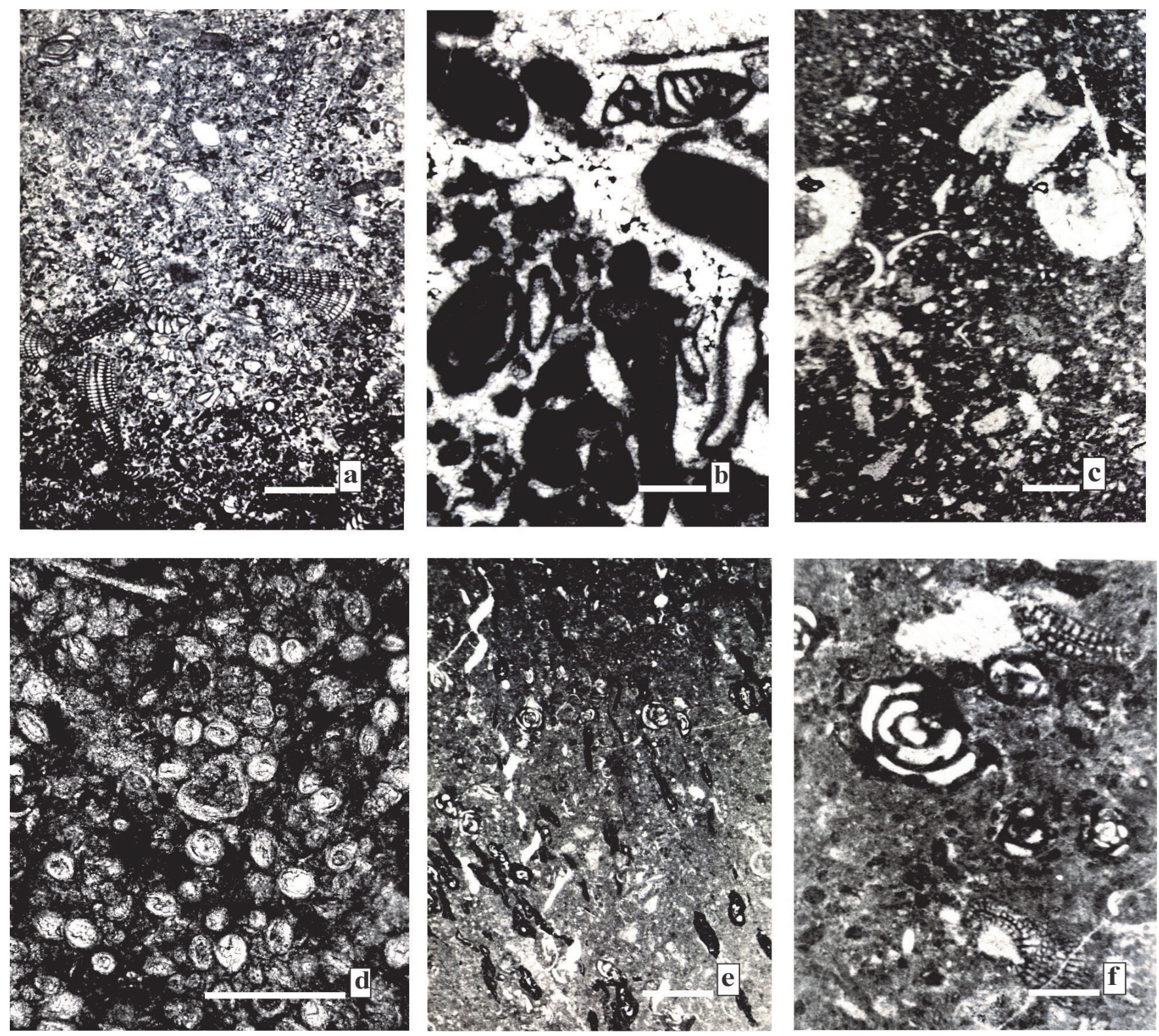

Figure 3 Microfacies of the upper part of the El Abra Formation. Scale bars $100 \mu \mathrm{m}$. a: Packstone-grainstone (Sample ET-2); b: Grainstone poorly classified with miliolids (Sample LLC-4); c: Worn algal packstone (Sample C-9); d: Calcisphere-rich packstone-wackestone (Sample C-10); e: Wackestone-packstone with a great abundance of miliolids and thin-shelled ostreids oriented in a parallel arrangement (Sample -LM-1); f: Benthic foraminiferal wackstone-packstone (Sample LM-5).

and algae; the grains and microfossils are strongly micritized (Figure 3b).

\subsubsection{THE GUADALCÁZAR SECTION (G)}

The Guadalcázar section $(\mathrm{G})$ is located NE of the city of San Luis Potosí $\left(22^{\circ} 64^{\prime} \mathrm{N}, 100^{\circ} 38^{\prime} \mathrm{W}\right)$. The studied succession belongs to the upper part of the El Abra Formation that crops out in the Aguaje de los García stream. It consists of a gray calcareous deposit $\sim 50 \mathrm{~m}$ thick of the Taninul Facies (Figure 5). The lithofacies is dominated by packstone and subordinate grainstone with the same foramin- 


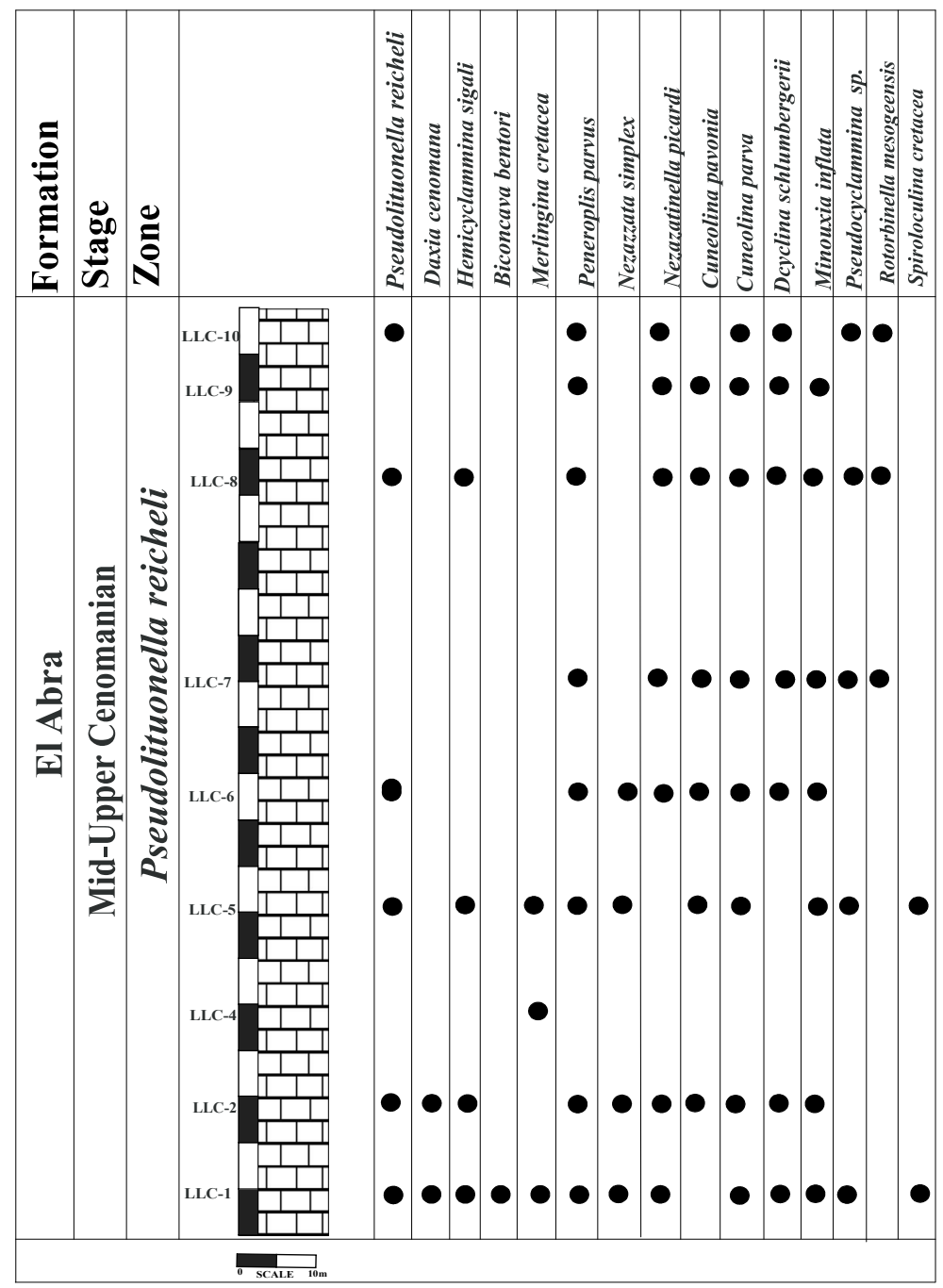

Figure 4 Llano del Carmen section.

iferal assemblage as the Llano del Carmen site but containing algae, such as Salpingoporella hasi and Clypeina sp.

The presence of sparitic cement represents an increase in energy in practically the same microfacies as at the Llano del Carmen site. This microfacies is interpreted as Standard Microfacies Type (SMF) 18 (Flügel, 2004) of Facies Zone 7 to 8 (Wilson, 1975) in the platform (open marine). The El Abra limestone is unconformably overlain by the Soyatal Formation, which here is $15 \mathrm{~m}$ thick.

\subsubsection{THE CERRITOS SECTION (C)}

The Cerritos section $(\mathrm{C})$ was measured on the San Luis Potosí-Cerritos road $\left(22^{\circ} 43^{\prime} \mathrm{N}, 100^{\circ} 28^{\prime} \mathrm{W}\right)$. It consists of $45 \mathrm{~m}$ of massive gray limestone from the upper part of the El Abra Formation of the Taninul Facies, and it is conformably overlain by the Soyatal Formation (Figure 6).

In the El Abra Formation we recognized the following 2 microfacies:

Microfacies 1-Benthic foraminiferal packstonegrainstone rich in pellets and pseudopellets. The percentage of components locally exceeds $50 \%$, forming a grain-supported fabric. The groundmass, mostly sparry cement, shows small remains of an original micritic matrix. The microfacies type could be comparable to SMF 18 "bioclastic grainstones and packstones with abundant benthic foraminifera or calcareous green algae" (Flügel, 2004). 


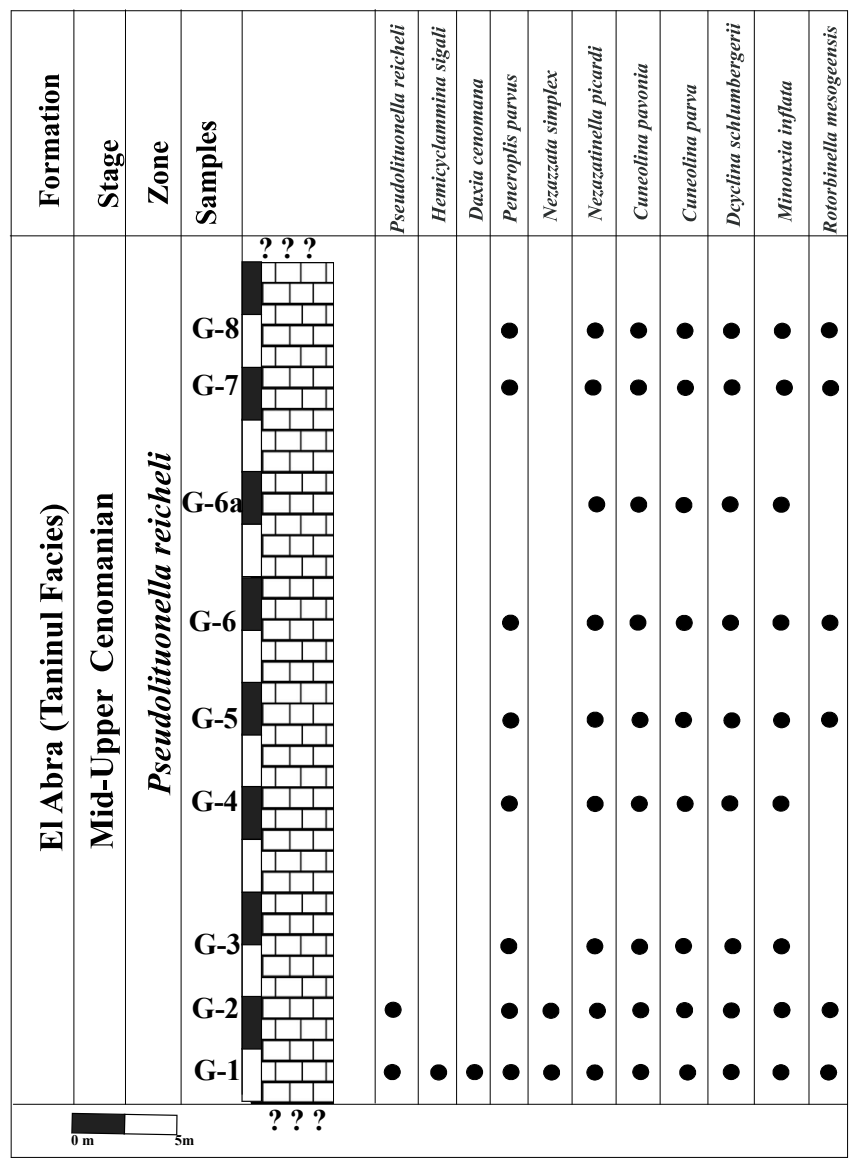

Figure 5 Guadalcazar section.

The depositional environment of this microfacies suggests a shallow marine environment above the normal wave base, within the euphotic zone in the open marine interior platform, corresponding to Facies Zone 7 of Wilson (1975). The fossil assemblage indicates precipitation in shallow subtidal zones with normal salinity, stable temperature conditions, and good oxygenation of the seawater. Microfacies 2-Worn algal packstone, within a fine-grained matrix containing a larger embedded amount of algae (Figure 3c). The foraminiferal community is reduced to small forms of Nezazzatinella picardi, miliolids, and rotalids. This change could be related to an increase in nutrient supply. This microfacies is similar to SMF 10, suggesting an open sea shelf environment of Facies Zone 7 of (Wilson 1975). The main components have been transported from high-energy to low-energy environments, and a variation in the water energy can be inferred from the increase in size of the bioclasts and groundmass grains (microsparite). This microfacies corresponds to Facies Zone 7 (interior platform, open marine environment).

Up-section, the lithology changes to marly limestone of the hemipelagic-pelagic Soyatal Formation represented by the next microfacies:

Microfacies 3-Pithonellid-rich packstone-wackestone, this microfacies contains a bloom of pithonellids embedded in a micritic matrix that varies locally in microsparitic cement (Figure $3 \mathrm{~d})$. The population of pithonellids can be up to more than $50 \%$ of the components in a mud to grain-supported fabric. In addition to the pithonellids, $r$ and $r-k$ strategist planktic foraminifera are also present, including Muricohedbergella delioensis, M. planispira, Heterohelix moremani, Heterohelix reussi, Macroglobigerinelloides caseyi, Whiteinella archaeocretacea, W. cf. W. aprica, W. baltica, W. brittonensis, and $W$ paradubia. The $r$-strategists are small to medium-sized species with unornamented tests and simple morphologies that have high reproductive potential and are adapted to eutrophic or unstable environments, and morphotypes as Whiteinella that connect the $r$ and $k$ morphogroups and are called $r / k$-intermediate species (Gebhardt et al., 2010). Small benthic foraminifera Dorothia sp., Gavelinella sp., Lingulogavelinella sp., and roveacrinids were identified. No microlamination or orientation of the components is recognizable; rather, it resembles an unsorted accumulation of microfauna in the micritic groundmass. This microfacies could be similar to types SMF 2 and 3 Flügel (2004) (wackestone to packstone with pithonellids and foraminifers) and a Facies Zone 2 to 3 of Wilson (1975) (deep shelf), but its depositional environment is certainly evidence of an initial drowning event.

\subsubsection{THE EL TEMAZCAL SECTION (ET)}

The analyzed section was measured in the Cerro Quemado locality $\left(22^{\circ} 38^{\prime} \mathrm{N}, 100^{\circ} 50^{\prime} \mathrm{W}\right)$. It is composed of $40 \mathrm{~m}$ of gray, massive limestone corresponding to the El Abra Formation, and is unconformably capped by a reddish calcareous shale unit. 


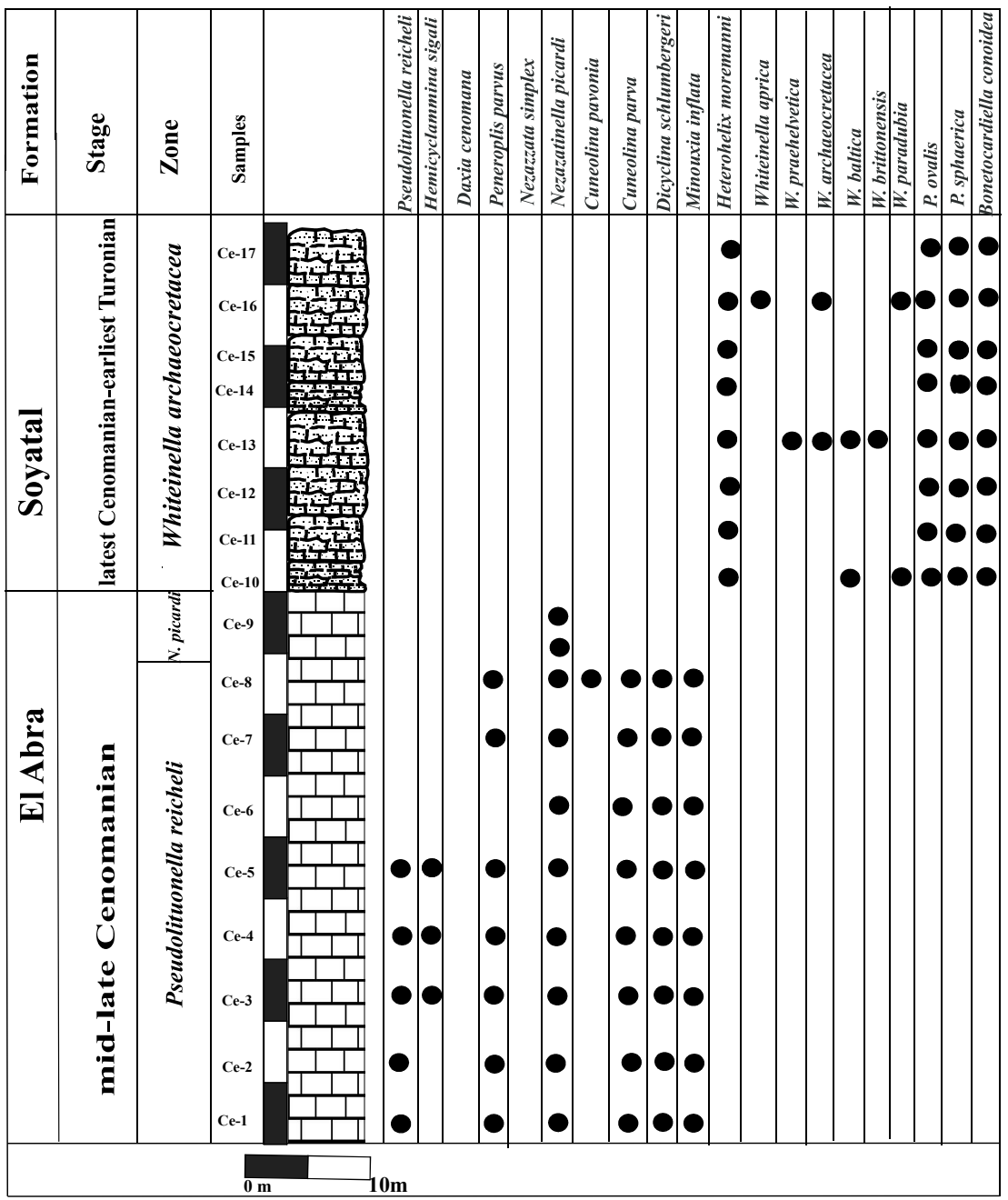

Figure 6 Cerritos section.

The limestone in this locality has packstonegrainstone texture and locally the component exceeds $60 \%$, forming a typical grain-supported fabric. The foraminiferal association is like that of the other sections, but the algae Neomeris cretacea is present. The standard microfacies type and the facies zone are similar to those at the other localities, which include SMF 8 to 10 in the Facies Zone 7 (Flügel, 2004; Wilson, 1975).

\subsubsection{THE EL ABRA FACIES}

\subsubsection{THE LA MINITA OUTCROP (LM)}

At this locality $\left(22^{\circ} 785^{\prime} \mathrm{N}, 100^{\circ} 85^{\prime} \mathrm{W}\right)$, we collected 8 samples of cream to light-gray limestone of the El Abra facies (Figure 7).
The La Minita outcrop displays several examples of cream limestone of the El Abra facies $(40 \mathrm{~m}$ thick). Two microfacies are defined: 1) a wackestone-packstone with reduced diversity but a great abundance of miliolids and thin-shelled ostreids, which are well-oriented in a parallel arrangement (Figure 3e). The presence of benthic foraminifera suggests shallow-water settings and the arrangement points to some control by the current. The components are embedded in a micritic matrix with a mud-supported fabric. These characteristics are comparable to SMF 8 (Flügel, 2004) of Facies Zone 7 in the interior platform; and 2) another that shows a benthic foraminifer-rich wackstone-packstone with a higher diversity of 


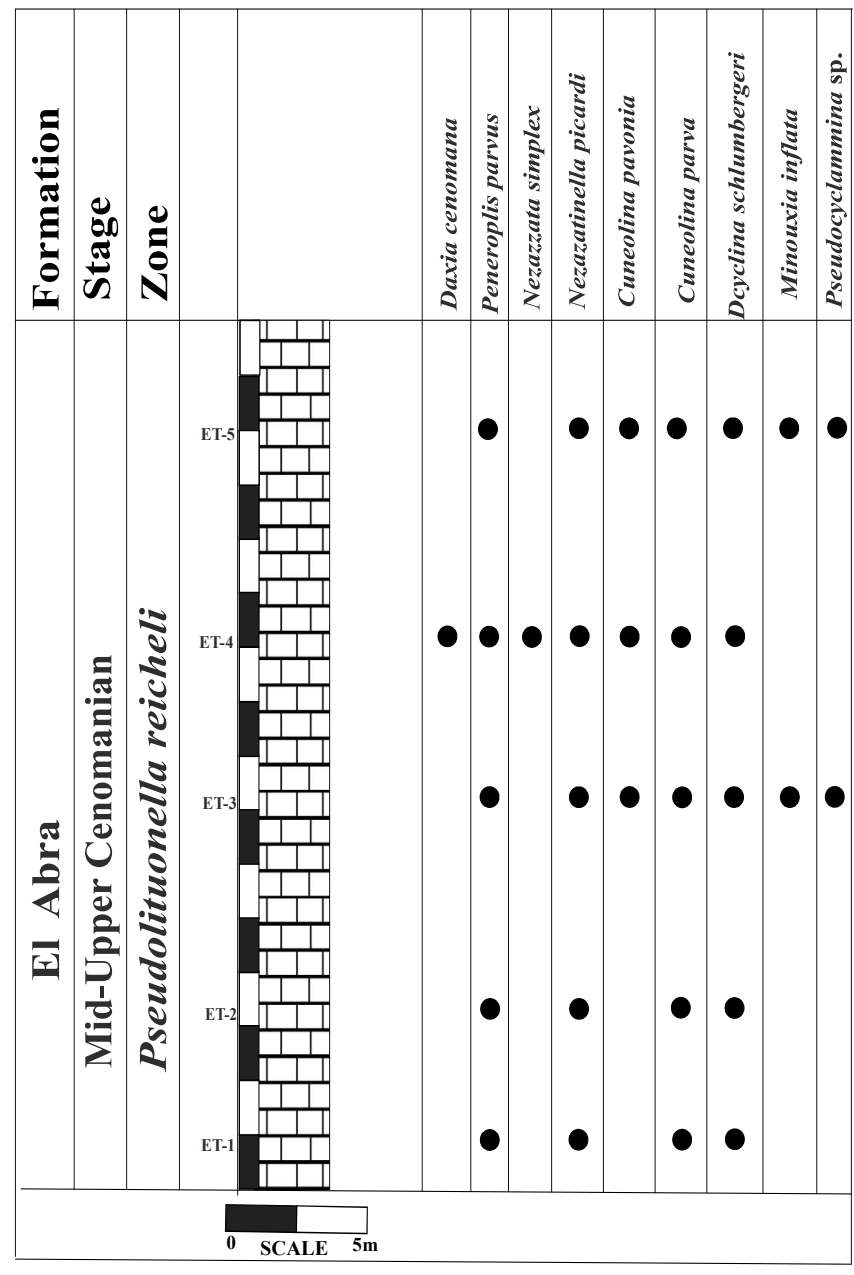

Figure 7 Temazcal section.

species including Pseudonummoloculina heimi, Ovalveolina maccagnoae, Dicyclina schlumbergeri, and Cuneolina pavonia (Figure 3f). The ground mass varies from micritic up to microsparitic and the fabric is much denser (grain-supported) in comparison with the first microfacies. This microfacies can be classified as SMF 10 to 11 of Facies Zone 7 in the interior platform with moderate energy.

\subsection{AGE}

Cretaceous larger benthic foraminifera are stratigraphically significant in shallow-water environments, where they are the most prominent marker fossils when other fossils such as the ammonites and planktic foraminifera are absent (Schroeder and Neumann, 1985).
Their stratigraphic value is based on their abundance, diversity, and evolutionary rates, which make these fossils a useful biostratigraphic tool for dating these deposits.

Few datings have been based on benthic foraminiferal studies from the western part of the VSLPP; consequently, this study provides a support for an accurate dating of this unit, which is determined as mid-late Cenomanian, comparable with those defined in other localities from the peri-Mediterranean area and southern Mexico. Moreover, it is an important contribution to the knowledge of the geographic distribution of these benthic foraminifers in the western part of the Tethys Realm.

In the interval studied we recognized two zones: Pseudolituonella reicheli Assemblage Zone and the overlain Nezzazatinella picardi Interval Zone.

\subsubsection{PSEUDOLITUONELLA REICHELI}

Assemblage Zone contains a foraminiferal assemblage composed of Pseudolituonella reicheli, Hemicyclammina sigali, Daxia cenomana, Merlingina cretacea, Cuneolina pavonia, Cuneolina parva, Nezzazata gyra, $\mathcal{N}$. simplex, Peneroplis parvus, Dicyclina schlumbergeri, Minouxia inflata, Nezzazatinella picardi, Spiroloculina cenomana, Pseudocyclammina sp., and Charentia sp.

\subsubsection{NEZZAZATINELLA PICARDI}

Interval Zone, which overlies the Pseudolituonella reicheli Assemblage Zone which, is characterized by a change in the benthic foraminiferal assemblage in which the larger foraminifera Pseudolituonella, Pseudocyclammina, Hemicyclammina, Daxia, and Merlingina disappear, reducing the foraminiferal community to forms of Nezzazatinella picardi, Rotorbinella mesogeensis, Praechrysalidina sp., and miliolids. A proliferation of gymnocodaceans, such as Permocalculus, is observed. This association later also disappeared when the platform was drowned.

The most important foraminifer in the studied material is Pseudolituonella reicheli, which has a short range and is considered to be of mid-late Cenomanian age.

Schroeder and Neumann (1985) indicated that P. reicheli is a species mainly of Cenomanian and possibly Turonian age; however Saint-Marc (1974) 
assigned the taxon a long stratigraphic range spanning from the mid-Albian to Turonian in Lebanon. In Italy, Luperto-Sinni (1966) assigned a late Cenomanian age to $P$. reicheli; Sartoni and Crescenti (1962) also found the species at the top of the Cenomanian (Cisalaveolina fraasi Zone). Chiocchini et al. $(1979,1984)$ stated that this foraminifer is limited to the upper Cenomanian rocks; this author used $P$. reicheli as a zonal marker. In France, P. reicheli is reported from the Cenomanian in W Aquitaine (Neumann 1962, 1965; Saint-Marc, 1966). Bilotte (1984) considered this species typical of the Cenomanian. Husinec et al. (2000) in Croatia and Decrouez (1977) in Greece reported P. reicheli from the mid-late Cenomanian. In Israel, it is recorded in the late Cenomanian and Turonian (Reiss, 1957). In Iran, Bozorgnia and Banafti (1964), and Sampó (1969) recorded this species in the Cenomanian. Schulze et al. (2004) indicated that $P$. reicheli only occurs in the Cenomanian in west central Jordan. In Turkey, Sari et al. (2009) used this microfossil as a late Cenomanian zonal marker. Recently, Frijia et al. (2015, p. 129) indicated that this species disappears at levels that can be correlated by carbon isotope stratigraphy to latest Cenomanian (Neocardioceras juddi ammonite zone); however, in the studied material we recorded the complete flooding of the platform in this time with deposits of opportunist planktic foraminifers and pithonellids (Whiteinella archaeocretacea Zone). In Mexico, Aguilera-Franco (2003) situated Pseudolituonella reicheli in the Pseudorhapydionina dubia Zone in the Guerrero-Morelos Platform in upper middle-upper Cenomanian. In the Chiapas region, Michaud (1987) regarded this species as middlelate Cenomanian.

Another important species found in the material examined is Daxia cenomana, which determines a mid-late Cenomanian age. This species was described by Cuvillier and Szakall (1949) from Audignon in France; they indicated that this genus appears to be restricted to the Cenomanian. It is considered a mid-Cenomanian species by Neumann (1965) and Moreau (1996) in the Charente Maritime region. In Spain, Barroso (2004) found
Daxia cenomana from the Burgos Province, dating it as mid-Cenomanian. Gräfe (2005) recorded $D$. cenomana in the Cenomanian and Turonian from the Basque-Cantabrian Basin. Caus et al. (2009) regarded this species as early-mid Cenomanian age in the Iberian Range. Ismail et al. (2009) document the occurrence of $D$. cenomana from the Cenomanian in Egypt.

Another form identified in the examined samples is Merlingina cretacea, which confirms the mid-late Cenomanian age. It was described from Negev, Israel by Hamaoui and Saint-Marc (1970) as from the Cenomanian. Schroeder and Neumann (1985) regarded the species as restricted to the middle part of the Cenomanian and the base of the Turonian. Caus et al. (2009) found this species in mid-upper Cenomanian rocks in the Iberian Peninsula.

Other conspicuous form in the studied samples is Hemicyclammina sigali, which is also considered mid-late Cenomanian, taking into account that it is associated with Pseudolituonella reicheli.

Hemicyclammina sigali was described for the first time by Maync (1953). He assigned it to the middle Cenomanian age. Berthou (1984a) recorded the occurrence of $H$. sigali restricted to the Cenomanian in the western Portuguese Basin. Later, Hart et al. (2005) studied a carbonate succession to outcrops along the valley of the Rio Mondego in the Lusitanian Basin, they stated that $H$. sigali is a particularly useful Cenomanian marker in many Tethyan areas. Bignot and Poisson (1974) recorded this species in the Cenomanian in the Katran, Dağ area, Turkey. Shirazi (2009) documented the presence of $H$. sigali in Iran in the mid-late Cenomanian. It has also been recorded in Syria (Mouty et al., 2003). Berthou and Bengtson (2007) considered $H$. sigali to be a reliable Cenomanian marker from the Sergipe Basin in Brazil.

An abundant form in the studied samples is Dicyclina schlumbergeri Munier-Chalmas (1887), associated with the mid-late Cenomanian species.

In Mexico, D. schlumbergeri is very common in Albian and Cenomanian strata; it has been reported from east of the VSLPP (Bonet, 1956; Tavitas et al., 1984) as well as in the Morelos Formation in the 
Guerrero-Morelos Platform (Aguilera-Franco and Allison, 2005), and in the Sierra Madre Formation in the Chiapas Range (Michaud, 1987). This species has been found in the Orizaba Formation in the Veracruz Basin (Sohl et al., 1991) and the Tepalcatepec Formation in Jalisco and Colima (Ponce de León, 1983; Ornelas, 1984).

The usual occurrence of Pseudonummoloculina heimi was recorded in the material examined. The species was described by Bonet (1956) for the first time from the El Abra Canyon in the VSLPP. He assigned it an Albian/Cenomanian age. In Mexico, this species has a similar geographical and stratigraphical distribution to that of Dicyclina schlumbergeri. The species is recorded in Texas, Florida, and Louisiana in USA (Conkin and Conkin, 1958). It has also been recorded in Italy (Luperto-Sinni 1966 and Spalluto, 2012), in Slovenia by Koch et al. (1998), and in Croatia by Husinec et al. (2000); it is also registered in Turkey (Sari et al., 2009) and Syria (Ghanem et al., 2012) in middle-upper Cenomanian strata.

A common species found in the analyzed samples is Cuneolina pavonia d'Orbigny. This species is known from Albian to Cenomanian in Tethys strata (Arnaud-Vanneau and Premoli-Silva, 1995). Peneroplis parvus is a common species in the samples analyzed. According to Schroeder and Neumann (1985), this form ranges from the latest Albian to mid-Cenomanian. According to Fleury (1980) this species is late Albian to early Cenomanian age from the Varassova Mountains in Greece. In Croatia, P. parvus was determined to be in the late Cenomanian (Velić and Vlahović, 1994).

We assigned a mid-late Cenomanian age to Peneroplis parvus in the material studied and thus its stratigraphic distribution could be extended from that given in other publications, in which the species is considered as mid-Cenomanian age (De Castro, 1965; Schroeder and Neumann, 1985).

The extinction of all the benthic foraminifera occurred in the Cenomanian/Turonian boundary interval by eutrophication of shallow marine environments and the terrigenous supply, as has been recognized in our material.
The El Abra Cenomanian shallow-water carbonates are overlain by the hemipelagic Soyatal Formation with a Pithonella acme and the $r$ and $r-k$ strategist planktic foraminifers Muricohedbergella delrioensis, M. planispira, Heterohelix moremani, H. reussi, Whiteinella archaeocretacea, W. aprica, W. brittonensis, W. baltica, W. paradubia, W praehelvetica, and other small benthic foraminifera; for example, Lingulogavellinella, Gavellinella and textularids. This interval is recognized as the Whiteinella archaeocretacea Partial Range Zone, which has been regarded as latest Cenomanian/earliest Turonian, which is impor tant because it constrains the age assigned to the El Abra Limestone.

\subsection{PALEOECOLOGY AND PALEOENVIRONMENT}

In modern environments, benthic foraminiferal distribution patterns are controlled by temperature, light intensity, nutrient content, substrate, and hydrodynamic energy. It is inferred that they had a similar distribution in the Mesozoic and Cenozoic (Hohenegger, 2000, 2004; BouDagher-Fadel, 2008).

The larger symbiotic-bearing foraminifera are indicative of warm waters (Murray, 1991). Their depth distribution is related to light, which is the main factor because it is required by the symbionts. The influence of the symbionts on the shape of the foraminiferal test as well as the hydrodynamic factor provides an important tool for paleoenvironmental interpretation. Thus, detached life forms with robust spherical tests indicate current-swept reef environments while thin fragile tests with maximum surface-to-volume ratios will be found in quiet low-light environments (Haynes, 1965). This is supported by the modern assemblage study. Recent larger foraminifera may occur as encrusters, periphyton (free-living on seagrass and calcareous algae), or living on or in the sediment (epifaunal, infaunal). In higher energy environments, encrusters and periphyton are the most common, while algal-film and sediment dwellers predominate under lower energy conditions (Hallock and Glenn, 1986; Murray, 2006). 
Recent Peneroplis and Spiroloculina are known as epiphytic forms (Langer, 1993) or living in sea grass (Hallock and Glenn, 1986).

In this study, benthic foraminifera, together with other biogenic components such as algae, as well as lithologic characteristics were used to reconstruct the paleoenvironmental conditions that existed during the El Abra deposit.

The El Abra Formation (Taninul Facies) in the studied successions, Llanos del Carmen, Cerritos and El Temazcal sections, is characterized by an abundant and diversified benthic foraminiferal assemblage, composed of Pseudolituonella reicheli, Hemicyclammina sigali, Daxia cenomana, Merlingina cretacea, Cuneolina pavonia, Cuneolina pavonia parva, Pseudocyclammina sp., Dicyclina schlumbergeri, Nezzazata gyra, $\mathcal{N}$. simplex, Nezzazatinella picardi, and Peneroplis parvus. The algae recorded are Bouenia pyigmaea and Neomeris cretacea, as well as the encrusters Lithocodium aggregatum and Thaumatoporella parvovesiculifera.

The great variety and diversity of the benthic foraminifers, together with algae and invertebrates such as rudists, gastropods, echinoderms, and calcareous worm tubes, as well as the peloidal bioclastic packstone-grainstone texture of the rock, suggest a shallow-water environment within the euphotic zone on the open marine platform during stable salinity and temperature conditions, permitting this oligotrophic association to develop and flourish. The occurrence of large-sized discoidal and conical benthic foraminifers such as Dicyclina, Cuneolina, and the encrusting habit of Thaumatoporella parvovesiculifera and Lithocodium, indicate medium hydrodynamic energy.

There is a conspicuous change in the top of the El Abra Formation. The foraminiferal community is reduced to a few benthic foraminifers such as Nezzazatinella picardi, miliolids, and rotalids, and the algae Permocalculus irenae and P. budaensis. The abundance of algae as well as decreased diversity of benthic foraminifera indicates a marine deposit associated with changes in the nutrient supply to the platform that caused the larger sized foraminifers adapted to oligotrophic conditions to disappear, reducing the assemblage to small forms, indicating a decrease of benthic-factory carbonate production (Schlager, 1981), which preceded the drowning of the platform. The Soyatal Formation overlies the El Abra limestone, which consists of a foraminiferal packstone-wackestone with an overabundance of pithonellids, $r$ and $r-k$ strategist planktic, and different benthic foraminifers such as gavellinelids, which indicate a deeper and eutrophic environment. These significant faunal and lithological changes are related to an early phase of the transgression that flooded the VSLPP in the latest Cenomanian (Whiteinella archaeocretacea Partial Range Zone).

A lateral change of facies of the El Abra Formation, termed the $\mathrm{El}$ Abra facies, is recorded in the La Minita outcrop, which is characterized by a cream limestone represented by a wackestone with abundant miliolids and ostreids adapted to survive within environments with varying salinities, these characteristics suggest a restricted shallow environment. Other microfacies is identified showing a larger diversity of species including Pseudonummoloculina heimi and Ovalveolina maccagnoae, other alveolinids, Dicyclina schlumbergeri and Cuneolina pavonia allow us to infer an intermediate semi-restricted shallow-water environment.

\subsection{SYSTEMATIC PALEONTOLOGY}

The benthic foraminifers contained in the limestone samples of the El Abra Formation are abundant and well preserved. The new suprageneric agglutinated foraminiferal assignment is based on the classification proposed by Kaminski (2014) for the agglutinated foraminifera, and Pawlowski et al. (2013 partim).

The thin sections are housed in the Paleontology Collection of the Institute of Geology (Universidad Nacional Autónoma de México).

Class FORAMINIFERA d'Orbigny, 1826

Subclass Globothalamea Pawlowski Holzmann and Tyszka, 2013

Order Lituolida Lankester, 1885

Suborder Nezzazatina Kaminski, 2004

Superfamily Nezzazatoidea Hamaoui and Saint-

Marc, 1970 

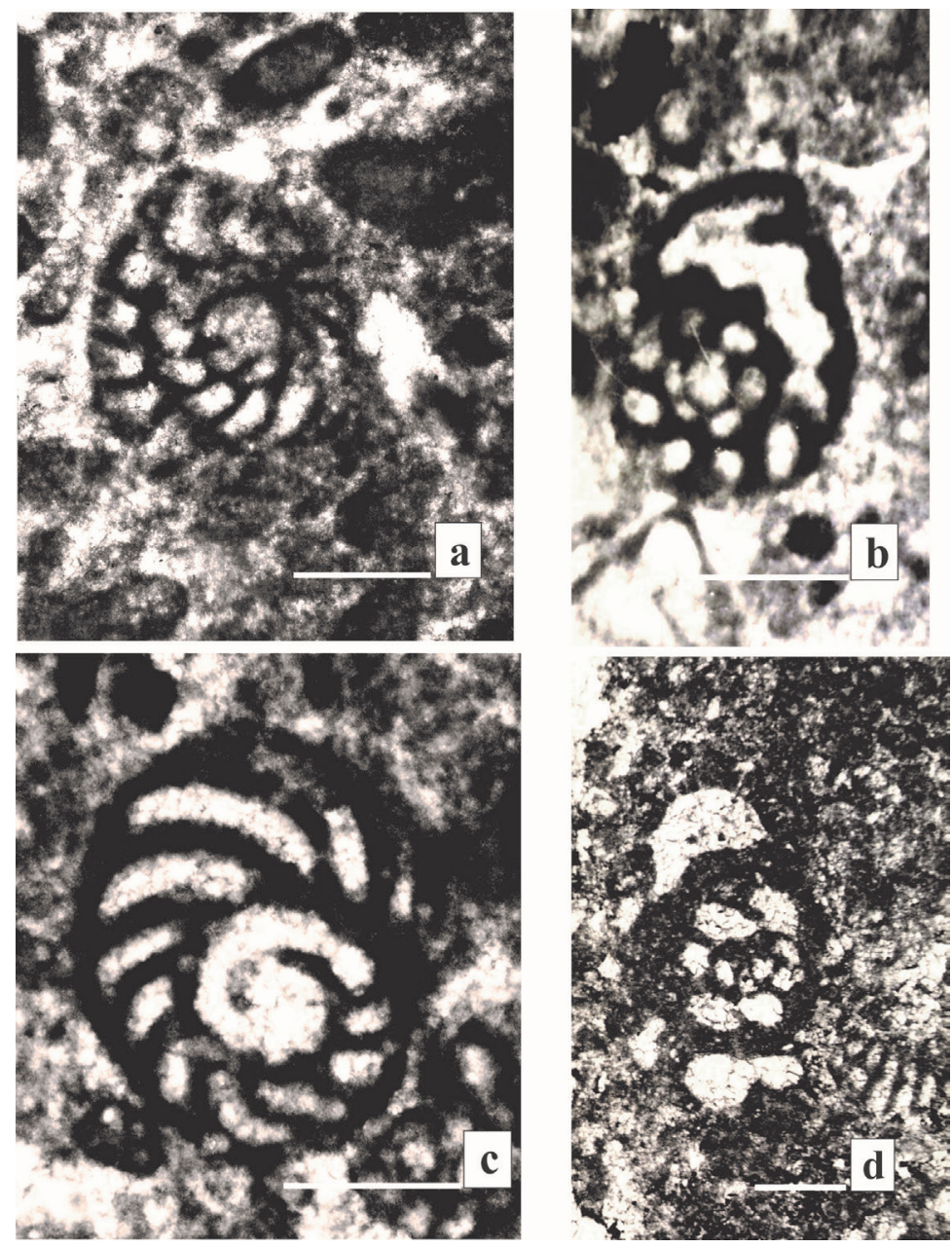

Figure 8 Mid-late Cenomanian foraminifera from the El Abra Formation (scale bar $200 \mu \mathrm{m}$ ). a: Biconcava bentori tangential section; b: Charentia sp. equatorial section (Sample G-2) (Sample LLC-1); c: Daxia cenomana equatorial section (Sample LLC-1); d: Pseudocyclammina sp. subaxial section (Sample LLC-2).

Family Nautiloculinidae Loeblich and Tappan, 1985

Genus Biconcava Hamaoui, 1965

Type species. Biconcava bentori Hamaoui, 1965

Biconcava bentori Hamaoui, 1965

(Figure 8a)

Biconcava bentori Hamaoui 1965, p. 14; Hamaoui and Saint-Marc, 1970, p. 304, pl. 18-21; Loeblich and Tappan, 1988, p. 71, pl. 55, figs. 1-4.

Description: Test planispirally coiled with three whorls, showing a rounded proloculus, the cham- bers growing slowly; curved sutures, but slightly curved in. The last whorl has 18 chambers.

Remarks: Loeblich and Tappan (1988) transferred Biconcava to Maycinidae due the absence of a rudimentary internal tooth plate described by Hamaoui and Saint-Marc (1970, p. 301). The former authors stated, "this genus is closest in appearance to Daxia but differs in being more evolute and in the aperture located in a vertical groove in the apertural face."

Genus Daxia Guvillier and Szakall, 1949

Type species: Daxia cenomana Cuvillier and Szakall, 1949 
Daxia cenomana Guvillier and Szakall, 1949

(Figure 8c, 9a)

Daxia cenomana Cuvillier and Szakall, 1949, p. 8, pl. 2, figs. 4-6; Maync, 1952, p. 55, pl. 11, fig. 3; Schroeder and Neumann, 1985, p. 15, pl. 1, figs. $1-8.1$.

Description: Test planispirally coiled; with a rounded proloculus followed by rhomboid-shaped chambers; the latest chambers are low and elongated with curved sutures. Some specimens in our material possess $12-16$ chambers in the last whorl. The measured height varies from 500 to $700 \mu \mathrm{m}$; the diameter of the proloculus is $30 \mathrm{~m} \mu$.

Remarks: Daxia cenomana differs from Daxia minima Laug and Peybernès (1979) of the Aptian (Pyrénées Basco-Béarnaises), in its larger size, thinner septa and sutures less depressed in equatorial section.

Occurrence: Daxia cenomana is considered a typical Tethysian species (Schroeder and Neumann, 1985), and has been recorded in France (Cuvillier and Szakall, 1949; Neumann, 1965; Bilotte, 1984), Spain (Calonge and Caus, 1996; Gräfe, 2005; Barroso, 2004; Caus et al., 2009), Portugal (Berthou, 1984b; Berthou and Lauverjat, 1979), and Egypt (Ismail et al., 2009; Anan et al., 2013).

VSLPP, it was recorded in the Llanos del Carmen, Cerritos, and Temazcal sections.

Family Nezzazatidae Hamaoui and Saint-Marc, 1970

Subfamily Nezzazatinae Hamaoui and SaintMarc, 1970

Genus Merlingina Hamaoui, 1965

Type species: Merlingina cretacea Hamaoui, 1965

Merlingina cretacea Hamaoui, 1965

(Figure 9c)

Merlingina cretacea Hamaoui, 1965, p. 7, pl. 9, fig. 6; pl. 14, fig. 14; Hamaoui and Saint- Marc, 1970, p. 315, pl. 22-27; Schroeder and Neumann, 1985, pl. 1, figs. 1-8, p. 37, pl. 15, figs. 1-9; Michaud, 1987, pl. 12, figs. 1-12.

Description: The specimen illustrated is a triangular section with initial part planispiral, later uncoiled and finally flaring; broad and low cham- bers, subdivided by tooth plate slightly curved inward from the lateral borders of the apertural face, having two or three basal digitations attaching to the septum of the preceding chamber; sutures sinuous.

Remarks: Merlingina differs from Nezzazata and Biconcava by having an uncoiled stage in adult specimens, with rapid enlarging of spire, and sutures more complex as well as the aperture with a more complex tooth plate (Hamaoui and SaintMarc, 1970).

Occurrence: Merlingina cretacea was described from a subsurface sample from Negev, Israel (Hamaoui and Saint-Marc, 1970). It has been recorded in Italy (Chiochini et al., 1984), Spain (Caus et al., 2009), Turkey (Sari et al., 2009), Oman (Philip et al., 1995), and Syria (Ghanem et al., 2012). In the Americas, this species was identified in Mexico from the Chiapas Platform (Michaud, 1987) and the Morelos Guerrero Platform (Aguilera-Franco, 2003), and in Peru (Jaillard and Arnaud-Vanneau, 1993).

VSLPP in the Llanos del Carmen section.

Genus Nezzazata Omara, 1956

Type species: Nezzazata simplex Omara, 1956

Nezzazata simplex Omara, 1956

(Figure 9f and 9g)

Nezzazata simplex Omara, 1956, p. 887, pl. 102, figs. 7-13; Hamaoui and Saint-Marc, 1970,p. 348, pl. 40 fig. 13; Schroeder and Neumann, 1985, p.33, pl. 11, figs. 1-11; Ettachfini and Andreu, 2004, p. 286, figs 8 b, c.

Description: Test sub-circular, trochospiral, ventral side convex, dorsal area moderately convex; the chambers increasing slightly in size as added; ventral sutures radial, slightly depressed with a small indentation in the septal suture, which points backwards away from the apertural face, umbilical area closed. The aperture extending from near the umbilical region at the base of the apertural face bending below the dorsal wall parallel to the periphery; the bend nearly forms an L-shaped orifice, with a flattened tooth-like outgrowth (Loeblich and Tappan, 1988, p. 83). 

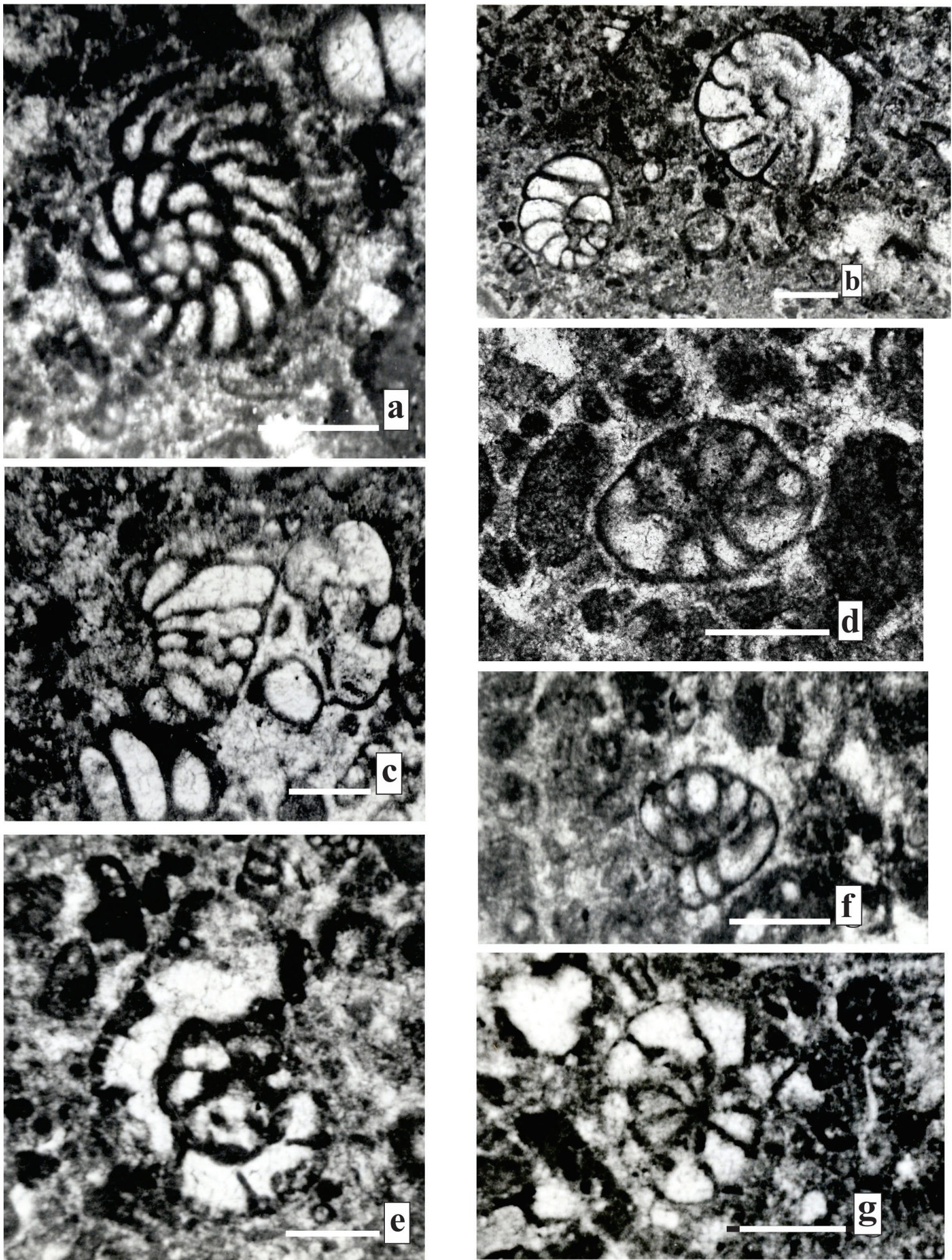

Figure 9 Mid-late Cenomanian foraminifera from the El Abra Formation (All scale bars $200 \mu \mathrm{m}$ except $\mathrm{f}$, g scale bar $500 \mu \mathrm{m}$. a: Daxia cenomana equatorial section (Sample ET-4); b: Nezzazatinella picardi equatorial section on the spiral and the umbilical side (Sample ET-4); c: Merlingina cretacea oblique section (Sample LLC-5); d: Nezzazata gyra oblique subequatorial section (Sample ET-4); e: Hemicyclammina sigali equatorial section (Sample LLC-1); f, g: Nezzazata simplex equatorial section on spiral and umbilical side (Sample LLC-1). 
Remarks: Nezzazata conica (Smout, 1956) differs from $\mathcal{N}$. simplex by possessing a very convex umbilical side and a smaller umbilicus. $\mathcal{N}$. simplex differs from $\mathcal{N}$. convexa (Smout, 1956) by possessing a flat to slightly convex spiral side rather than a strongly convex planispiral side; and is distinct from $\mathcal{N}$. concava (Smout, 1956) because it has a strongly concave spiral view. Hauterivian Nezzazata germanica Omara and Strauch (1965) is poorly described and could be incorrectly assigned to Nezzazata because it does not have the tooth plate (Arnaud-Vanneau and Sliter, 1995).

Occurrence: Nezzazata simplex was recorded in the lower part of the Cenomanian of Gebel Nezzazat, west central Sinai by Omara (1956). Omara and Strauch (1965) extended the stratigraphic range to the early Turonian. Ismail et al. (2009) recorded it in the late Cenomanian. This species has been recorded from the Cenomanian in Italy (Simone et al., 2012), Croatia (Husinec et al., 2000), and Turkey (Sari et al., 2009); Syria (Ghanem et al., 2012). In Mexico, it has been found in the Chiapas Platform (Michaud, 1987) and the Guerrero Platform (Aguilera-Franco, 2003). It has also been found in Honduras by Scott and Finch (1999). VSLPP in the Llano del Carmen and Guadalcazar sections.

\section{Nezzazata gyra (Smout, 1956)}

(Figure 9d)

Beggia gr. gyra Smout, 1956, p. 340, pl. 1, figs. 1-9; Nezzazata gyra (Smout) Schroeder and Neumann, 1985, p. 34, pl. 12, fig. 9.

Description: Test plano-convex with three whorls on the spiral side; umbilicus closed, chambers with a narrow internal plate extending back from one septum to the previous septum resulting in a kink or indentation in the septal suture, typical aperture with an apertural tooth.

Remarks: Nezzazata gyra differs from $\mathcal{N}$. simplex by possesing a false umbilicus and from the Aptianearly Albian $\mathcal{N}$. isabellae (Arnaud-Vanneau and Sliter, 1995) by having larger size and a well-developed tooth plate which extends to the previous aperture.
Occurrence: Nezzazata gyra has been reported from the Cenomanian in Italy (Luperto-Sinni, 1966), southern Croatia (Husinec et al., 2009), Syria (Ghanem et al., 2012), Egypt (Ismail et al., 2009), the subsurface of Iraq (Bernaus and Masse, 2006), and Turkey (Farinacci and Yeniay, 1986).

VSLPP in the Llano del Carmen, Guadalcazar and Cerritos sections.

Genus Nezzatinella Darmoian, 1976

Type species: Nezzazatinella adhami Darmoian, 1976, p. 492

\section{Nezzazatinella picardi (Henson, 1948a) (Figure 9b)}

Valvulammina picardi Henson, 1948a, p. 613, pl. 15, figs. 1,3, pl. 18, figs.3-6; Nezzazatinella picardi (Henson) Aguilera-Franco et al., 2001, p. 248, fig. 9 i; Sari et al., 2009, p. 60, pl. 2, figs. 12, 13; Rahimpour-Bonab et al., 2012, p. 28, fig. 8 p.

Description: Test trochospiral, dorsal side flat or slightly convex; with chambers arranged in 1-2 whorls; they are narrow, elongated, with the last chamber flaring backwards, 11 chambers in the last whorl, sutures radial, depressed; the apertural area is wide with a large curved slit, may have secondary apertures in a curved row or scattered over the umbilicus region (Henson, 1948a; Loeblich and Tappan, 1988).

Remarks: Nezzazatinella picardi differs from preConiacian $\mathcal{N}$. adhami Darmoian (1976) by having fewer and differently shaped chambers and a larger aperture with secondary apertures in a curved row or scattered over the apertural face. This species differs from Turonian $\mathcal{N}$. aegyptiaca (Said and Kenawy, 1957) by having more chambers in the last whorl, and more depressed sutures in the umbilical side.

Nezzazatinella picardi is distinguished from Barremian/Aptian $\mathcal{N}$. macoveii Neagu (1979) by possesing a smaller test, a rounded periphery, chambers less elongated, and radial sutures in the umbilical side in place of a test in later species that measures more than $1 \mathrm{~mm}$, with a lobate and angled margin, and strongly curved sutures in the umbilical view. 
Occurrence: $\mathcal{N}$. picardi occurs widely in Upper Cretaceous rocks. This species was described for the first time as Valvulammina picardi from the Santonian beds of Egypt (Henson, 1948a). Forms comparable to it were later described and drawn from the Albian and Cenomanian of Israel, Lebanon, Iran, Slovenia, Croatia, Turkey, and Portugal (Reiss, 1961; Bozorgnia and Banafti, 1964; Dozet and Šribar, 1998; Hamaoui, 1966; Hamaoui and Saint-Marc, 1970; Moro and Jelaska, 1994; Koch et al., 1998; Sari et al., 2009, Berthou and Lauvejat, 1979).

VSLPP in the Llanos del Carmen, Cerritos, and Temazcal sections.

Order Loftusiida Kaminski and Mikhalevich, in Kaminski, 2004

Suborder Loftusiina Kaminski and Mikhalevich, in Kaminski, 2004

Family Cyclamminidae Marie, 1941

Subfamily Hemicyclammininae Banner, 1966

Genus Hemicyclammina Maync, 1953

Type species: Hemicyclammina sigali Maync, 1953

\section{Hemicyclammina sigali Maync, 1953}

(Figure 9e)

Hemicyclammina sigali Maync, 1953, p. 148, figs. 1-5; Saint-Marc, 1970, p. 232, pl. 3, figs. 4, 5; Shirazi et al., 201 1, p. 783, pl. 2, fig. 11.

Description: Test planispiral, shows a rounded to subacute periphery, with a small proloculus, and a last chamber incompletely subdivided by a discontinuous straight or slightly curved septum; wall agglutinated, outer layer imperforate, and sub-epidermal layer uniformly alveolar; the lower part of the septa coalesces as an imperforate basal layer against the previous whorl, in equatorial section appearing very short and originally termed semisepta (Maync, 1953; Loeblich and Tappan, 1988).

Remarks: Hemicyclammina sigali differs from Albian H. whitei (Henson, 1948b) because the latter species possesses the septa in contact with the test periphery at right angles to form chambers that are almost quadrangular (in equatorial section). In axial section $H$. sigali is more compressed.
The Coniacian/Santonian Hemicyclammina chalmasi (Schlumberger, 1899) differs from $H$. sigali by having a thick and coarsely agglutinated wall and large test with chambers increasing in height, producing a peneropliform test.

Occurrence: Hemicyclammina sigali was described by Maync (1953) from the middle Cenomanian of the Constantine Province in Algeria. This species is recorded in Portugal by Hart et al. (2005), Italy (Simone et al., 2012), Turkey (Bignot and Poisson, 1974), Iran (Shirazi, 2009), Syria (Mouty et al., 2003), Jordan (Weidich and Al-Harithi, 1990), and Brazil (Berthou and Bengtson, 2007).

VSLPP in the Llanos del Carmen

Subfamily Choffatellinae Maync, 1958

Genus Pseudocyclammina Yabe and Hanzawa, 1926

Type species: Cyclammina lituus Yokohama, 1890

\section{Pseudocyclammina sp.}

(Figure 8d)

Description: Test planispiral with a rounded periphery; composed of three whorled chambers growing rapidly; sutures oblique, wall coarsely agglutinated with a thick subepidermical network with numerous alveoles closely spaced in the agglutinated wall and septa (Loeblich and Tappan, 1988).

Occcurrence: VSLPP in the Llanos del Carmen, Cerritos, El Temazcal sections.

Suborder Biokovinina Kaminski, 2004

Superfamily Biokovinacea Gŭsić, 1977

Family Charentididae Loeblich and Tappan, 1985

Genus Charentia Neumann, 1965

Type species: Charentia cuvillieri Neumann, 1965

Charentia sp.

(Figure 8b)

Description: Test planispiral later partly uncoiled with ten chambers in last whorl; the periphery is rounded; imperforate wall pierced by cylindrical canaliculi resembling keriotheka or pseudoalveolar structure; wall of the early chambers and apertural surface solid, noncanaliculate; 
the portion of the apertural surface beneath the aperture distinctly thickened to form a triangular chomata-like projection.

Remarks: Charentia sp. differs from Charentia cuvillieri Neumann (1965) by having fewer whorls and chambers.

Occurrence: VSLPP in the El Temazcal section.

Suborder Ataxophragmioidea Schwager, 1877

Superfamily Ataxophragmiacea Schwager, 1877

Family Cuneolinidae Saidova, 1981

Subfamily Cuneolininae Saidova, 1981

Genus Cuneolina d'Orbigny, 1839

Type species: Cuneolina pavonia d'Orbigny, 1846

Cuneolina pavonia d'Orbigny, 1846

(Figure 10a and 10b)

Cuneolina pavonia d'Orbigny, 1846, p. 253, pl. 21, figs. 50-52; Chiocchini et al., 1984 p. 181, pl. 5, fig. 1; Tasli et al., 2006, p. 529, fig. 6 L; Sari et al., 2009, p. 423 , pl. 3-7.

Description: Test compressed conical to flabelliform, early trochospire followed by very broad, low biserially arranged chambers, commonly compressed parallel to the plane of biseriality; interior subdivided into nearly rectangular chamberlets by radial partitions positioned perpendicular to the outer wall and projecting inward toward the plane of biseriality, and by horizontal partitions paralleling the septa; wall agglutinated, imperforate, with reticulate subepidermal layer (cf. Loeblich and Tappan, 1988, p. 48).

Remarks: The two species reported most often are Cuneolina pavonia d'Orbigny and C. parva Henson. C. pavonia is flabelliform and tends to be slightly larger and have a greater apical angle than C. parva, which is conical and elongate (Arnaud-Vanneau and Sliter, 1995; Arnaud-Vanneau and Premoli-Silva, 1995).

Cuneolina pavonia d'Orbigny (1846) differs from Santonian Cuneolina conica d'Orbigny (1850) by having a broader test. C. pavonia differs from Aptian/Albian Cuneolina sliteri Arnaud-Vanneau and Sliter (1995) by having a larger size and flabel- liform test instead of a triangular test with a short biserial stage with 6 or 7 chambers in later species. Occurrence: VSLPP in the Llanos del Carmen, Cerritos, Temazcal sections.

Cuneolina parva Henson, 1948a

(Figure 10c to 10f)

Cuneolina pavonia parva Henson, 1948a, p. 624-627, pl.14, figs. 1-6, pl. 17, figs. 7-12, pl. 18 figs. 12-14; Cuneolina parva Arnaud-Vanneau and Sliter, 1995, pl. 4, figs. 6-9; Filkorn and Scott, 2011, p. 184, figs. 4, 11-12.

Description: Test compressed, conical. Embryonic apparatus composed of a large, oval protoconch covered by a deuteroconch followed by a broad, low biserial stage. Chambers compressed parallel to the plane of biseriality and subdivided by radial beams, and one or two transverse rafters that produce a subepidermal rectangular network.

Remarks: Cuneolina parva was described by Henson (1948a) from the Santonian of Egypt. This species differs from C. pavonia d'Orbigny (1846) by possessing a smaller test with a large megalosphere and smaller biserial stage as well as having a smaller apical angle than $C$. pavonia has two to three transverse rafters in the chambers compared to one to two in C. parva (Arnaud-Vanneau and Sliter, 1995; Arnaud-Vanneau and Premoli-Silva, 1995). Cuneolina parva is reported from AlbianCenomanian strata and C. pavonia from uppermost Albian to Santonian (Filkorn and Scott, 2011). C. parva differs from Barremian/Aptian C. hensoni Dalbiez (1958) by having a dense network of radial partitions and more common occurrence of tranverse rafters. C. parva is similar in cross section to the Maastrichtian Iraquian C. cylindrica Henson (1948a). The latter possesses a remarkable triangular test and almost cylindrical early stage.

Occurrence: The species is mostly known from the southern margin of the Tethys in the Middle East, Egypt, Greece, Italy, Albania, Yugoslavia, and North Africa, and from the northern margin in France and Spain (Arnaud-Vanneau and Premoli-Silva, 1995), and in Mexico: as Cuneolina 

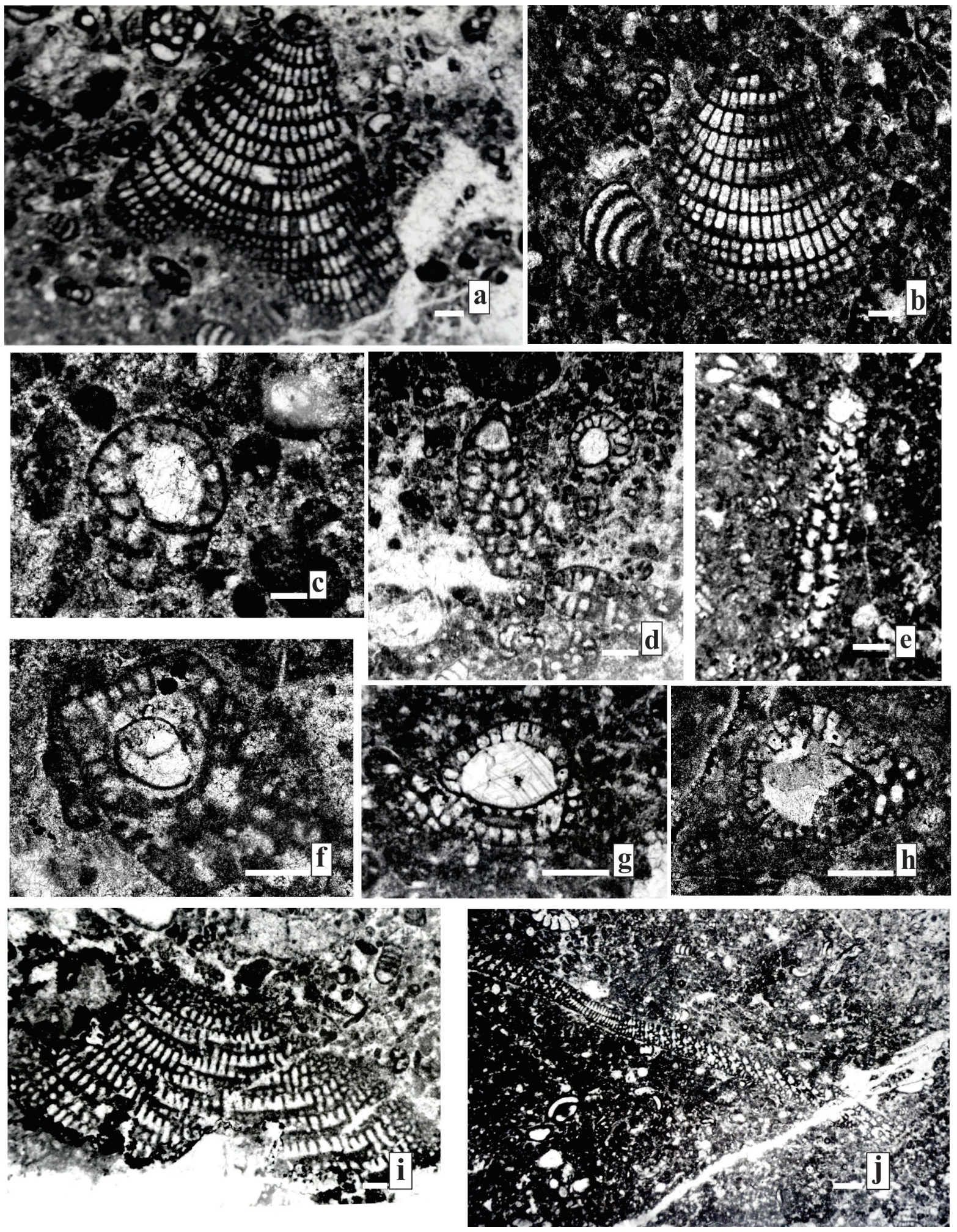

Figure 10 Mid-late Cenomanian foraminifera from the El Abra Formation. a: Cuneolina pavonia axial section (Sample G-5); b: Cuneolina pavonia axial section (Sample ET-1); c: Cuneolina parva axial section (Sample LLC-5); d: Cuneolina parva axial section (Sample ET-1); e: Cuneolina parva axial section (Sample LLC-5); f: Cuneolina parva axial section (Sample LLC-5); g: Dicyclina schlumbergeri axial section equatorial section showing the great proloculus (Sample G-5); h: Dicyclina schlumbergeri axial section (Sample LLC-5); i: Dicyclina schlumbergeri axial section subequatorial section (Sample LLC-2); j: Dicyclina schlumbergeri subaxial section (Sample G-5). 
walteri (in Scott and González-León 1991, p. 58; Filkorn and Scott, 2011); in Florida from subsurface samples (Cushman and Applin, 1947).

VSLPP in the Llanos del Carmen, Cerritos, Guadalcazar, and the El Temazcal sections.

Family Dicyclinidae Loeblich and Tappan, 1964 Genus Dicyclina Munier-Chalmas, 1887

Type species Dicyclina schlumbergeri Munier Chalmas, 1887

Dicyclina schlumbergeri Munier Chalmas, 1887

(Figures $10 \mathrm{~g}$ to $10 \mathrm{j}$ )

1887 Dicyclina schlumbergeri Munier Chalmas, p. xxx-xxxi; Schlumberger and Choffat, 1904, p. 362, fig. 1, p. 363, fig. 2; Bonet, 1956, p. 406, pls. 5-7; Sari et al., 2009, p. 61, pl. 3, figs. 8, 9.

Description: Test discoidal, flattened, slightly undulating, initial stage slightly inflated; the megalospheric generation consists solely of the proloculus measuring $700 \mu \mathrm{m}$. Later annular chambers added alternating on either side of the test, interior subdivided by numerous thin radial partitions, perpendicular to the outer wall and aligned from chamber to chamber. Wall agglutinated with an imperforate epidermis. The exoskeleton comprises beams and rafters organized in a subepidermic network (Loeblich and Tappan, 1988).

Remarks: Cherchi and Schroeder (1990) stated that Dicyclina was until recently assigned solely to Dicyclina schlumbergeri, a taxon ranging from the late Albian to Maastrichtian (Bilotte, 1984); however, these authors showed that Dicyclina comprises at least two species the mid-Cenomanian $D$. simplex and the Coniacian/Santonian D. schlumbergeri. These taxa were differentiated based on the different degree of development of the embryonic megalospheric apparatus. We assigned our specimens to $D$. schlumbergeri, which we consider to be valid because the Mexican specimens have a large, complex embryon (Figure 10g). D. schlumbergeri differs from the Iranian Cenomanian D. sampoi by not having a special layer of the secondary chamberlets in the uppermost part of the supraembryonic zone and the lowermost part of subembryonic zone (Cherchi and Schroeder, 1990).

Occurrence: $D$. schlumbergeri is widely distributed in the Tethys; it has been reported in Italy (Checconi et al., 2008), Portugal (Berhou and Lauverjat, 1979), Slovenia (Koch et al., 1998), Spain (Ullastre and Masriera, 2006), the Vardar region, Macedonia (Polavder, 2003), Turkey (Farinacci and Yeniay, 1986; Tasli, 2006; Robertson, et al., 2013), Iran (Afghah et al., 2014), and Morocco (Ettachfini et al., 2005; Lézin et al., 2012).

VSLPP in the Llanos del Carmen, Cerritos, Guadalcazar, and El Temazcal sections.

Suborder Orbitolinina Kaminski, 2004

Superfamily Coskinolinoidea Moullade, 1965

Family Coskinolinidae Moullade, 1965

Genus Pseudolituonella Marie, 1954

Type species: Pseudolituonella reicheli Marie, 1954

Pseudolituonella reicheli Marie, 1954

(Figure 11a)

Pseudolituonella reicheli Marie 1954, p. 117-119, text-fig. 2a-b; Luperto-Sinni, 1966, p. 149, pl. 10, fig. 1; Chiochini et al., 1984, p. 181, pl. 5, fig. 15; Schroeder and Neumann, 1985, p. 27, pl.8, figs. 1-9; Michaud, 1987, pl. 11, fig. 2; Loeblich and Tappan, 1988, p. 155, pl. 166, figs. 7-11; Aguilera-Franco et al., 2001,p. 248, fig. 9d; Sari et al., 2009, p. 61, pl. 3, fig. 10.

Description: Follows Loeblich and Tappan (1988, p. 155): Test elongate, conical, early portion with a short trochospiral stage, later with broad, low uniserial chambers divided by depressed sutures; interior chamber with tubular pillars projecting upward from the margins of the circular apertures but not completely crossing the chambers; wall microgranular, imperforate. The aperture is cribate with numerous pores in the center of the apertural face.

Remarks: Pseudolituonella reicheli differs from lower Aptian P. conica Luperto-Sinni and Masse (1993) because the latter species has the initial trochospiral stage in an eccentric position, and a thinner wall. 

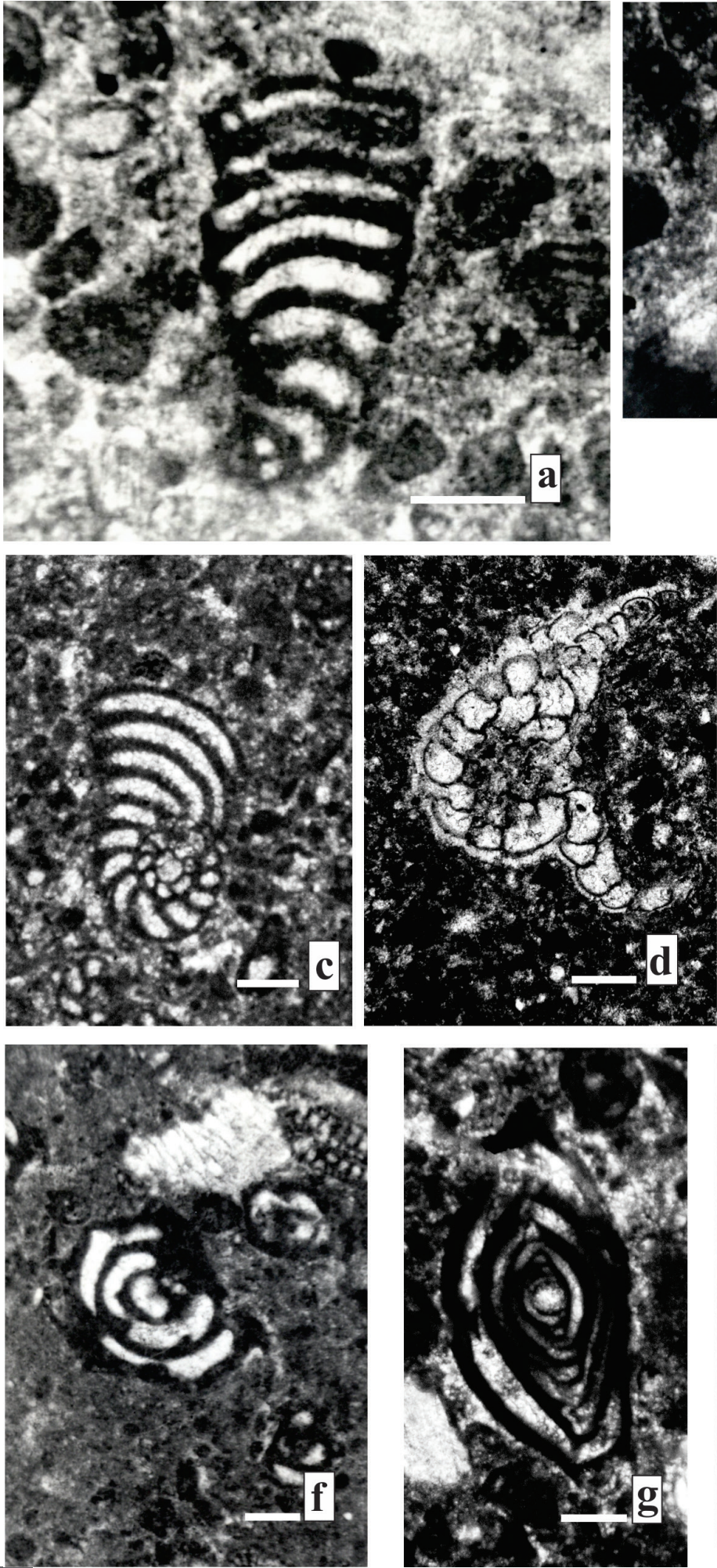
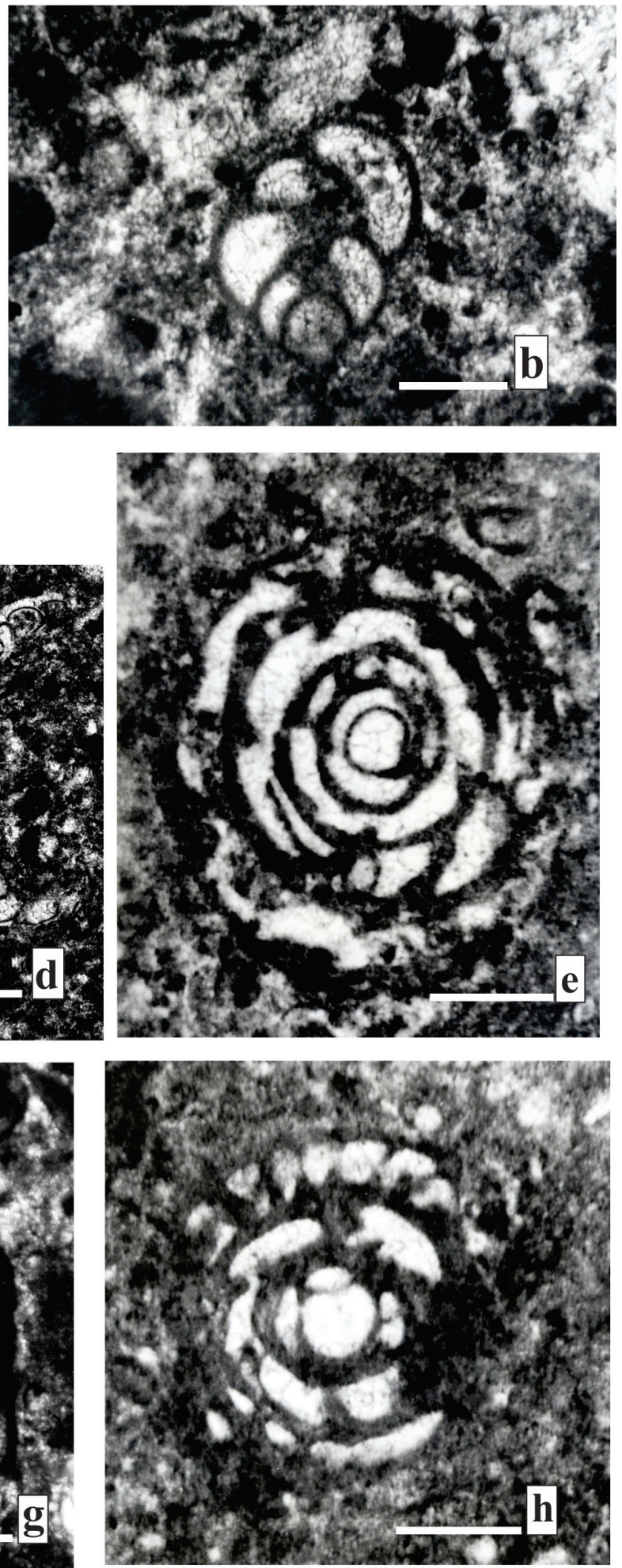

Figure 11 Mid-late Cenomanian foraminifera from the El Abra Formation (all scale bars $200 \mu \mathrm{m}$ ). a: Pseudolituonellareicheli axial section (Sample LLC-1); b: Minouxia inflata axial section (Sample G-1); c: Peneroplis parvus axial section (Sample ET-1); d: Archaecyclus cenomanianus (Sample LLC-5); e: Ovalveolina maccagnoae equatorial section (Sample LM-5); f: Pseudonummoloculina heimi subequatorial section (Sample LM-5); g: Spiroloculina cenomana axial section (Sample C-3); h: Ovalveolina maccagnoae subaxial section (Sample LM-5). 
Barremian Pseudolituonella gavonensis Foury (1968) is different from $P$. reicheli by having a streptospiral early stage. $P$. reicheli differs from upper Santonian P. mariae Gendrot (1968) by having a larger test and reduced trochospiral stage, and more developed uniserial stage compared to the latter species, possessing only two or three chambers in the uniserial portion.

Occurrence: Pseudolituonella reicheli is a typical Tethysian species. Its geographical and stratigraphical distribution has already been discussed above.

VSLPP in the Llanos del Carmen and Cerritos sections.

Order Textulariida Delage and Hérouard 1896, emended Kaminski, 2004

Superfamily Eggerelloidea Cushman, 1937

Family Eggerellidae Cushman, 1937

Subfamily Minouxinae Loeblich and Tappan, 1986

Genre Minouxia Marie, 1954

Type species: Minouxia guembelitrioides Marie, 1954, p. 119

Minouxia inflata Tronchetti and Zijlstra-Bessais, 2002

(Figure 11b)

Minouxia inflata Tronchetti and Zijlstra-Bessais, 2002, p. 541, pl. 1; figs. 1-7; pl. 2, figs. 1-8; pl. 3, figs. 1-4; pl. 4, figs. 3-5

Description: Test conical, elongate, triserial with globular and inflated chambers, the last chamber larger, sutures depressed; wall thin, agglutinated, finely canaliculate, aperture multiple that consists in circular openings in the latest chamber on a trematophore-like plate that covers the umbilical region (Loeblich and Tappan, 1988; Tronchetti and Zijlstra-Bessais, 2002).

Remarks: Minouxia inflata was described from Cenomanian beds of central Tunisia by Tronchetti and Zijlstra-Bessais (2002).

Minouxia differs from Tetraminoxia by having a triserial arrangement instead of quadriserial cham- bers arranged throughout as in the latter genus. Minouxia inflata is different from Maastrichtian M. guembelitrioides Marie (1954) by having fewer chambers, the last chamber covering the preceding chambers.

Minouxia inflata differs from Santonian M. conica Gendrot (1963) by having a larger test and globular chambers in place of chambers longer than wide in a conical test.

Minouxia inflata shows globular chambers in axial sections like Santonian M. lobata Gendrot (1963). Occurrence: VSLPP in the Llanos del Carmen, Cerritos, Guadalcazar, and Temazcal sections.

Subclass Tubothalamea Pawlowski, Holzmann, Tyszka, 2013

Order Miliolida Delage and Hérouard, 1896

Superfamily Miliolacea Ehrenberg, 1839

Family Spiroloculinidae Wiesner, 1920

Genus Spiroloculina d'Orbigny, 1826

Type species: Spiroloculina depressa d'Orbigny, 1826

Spiroloculina cenomana Chiocchini, 2008

(Figure 11g)

Spiroloculina cenomana Chiocchini, 2008, p. 187, pl. II, fig. 1.

Description: Test elliptical in outline, with strongly carenate extremities; last chambers changing plane of coiling and showing a sigmoid arrangement, and truncate periphery; sphaeric proloculus followed by a tubular second chamber one whorl in length, the last part with four pairs of chambers added in a single plane; aperture at open end of the final chamber consists of simple or bifid tooth commonly on a short neck. Wall is calcareous, imperforate, porcelanaceous (Chiocchini, 2008).

Remarks: Spiroloculina cenomana differs from S. cretacea due to the former having a sigmoidal chamber arrangement and a truncate periphery.

Occurrence: VSLPP in the Llanos del Carmen, Cerritos, Guadalcazar, and the El Temazcal sections. 
Family Hauerenidae Schwager, 1876

Pseudonummoloculina Calvez, 1988

Type species: Pseudonummoloculina aurigerica Calvez, 1988

Pseudonummoloculina heimi (Bonet, 1956)

(Figure 11f)

Nummoloculina heimi Bonet, 1956, p. 402, pl. 3, 4; Conkin and Conkin, 1958, p. 156, pl. 1, figs. 1-10; Michaud, 1987, p. 268, pl. 3, fig. 15; Pseudonummoloculina heimi (Bonet) Scott and González-León, 1991, p. 61, pl. 5L; Sari et al., 2009, p. 62, pl. 4, figs. 6,7

Description: Test discoidal, streptospirally involute, with a megalosphere provided with a miliolid bottle-neck (goulot) and at least in adult growth stages, with more than two chambers per whorl; wall calcareous porcelanaceous.

Remarks: The genus Pseudonummoloculina is represented by four species: P. aurigerica Calvez from the early to middle Albian of the Pyrenees, France; P. heimi (Bonet, 1956) from the Albian to Cenomanian of Mexico; P. robusta (Torre, 1966) from the Senonian of Italy; and $P$. irregularis (Decrouez and Radoičić, 1977) from the Santonian-Campanian of W Serbia. Pseudonummoloculina heimi differs from early to middle Albian ovoidal P. aurigerica by having a discoidal test and a more reduced early stage but a more developed final stage (Mancinelli and Chiocchini, 2006). Senonian Pseudonummoloculina robusta differs from $P$. heimi by possessing an inflated test and a very thick wall. The Santonian/ Campanian $P$. irregularis differs from $P$. heimi by having more chambers per whorl and a plane of coiling which changes irregularly.

Occurrence: $P$. heimi is widely distributed in the Albian/Cenomanian of the Gulf Coast and other localities from the Mediterranean area.

VSLPP, the La Minita locality.

Superfamily Alveolinacea Ehrenberg, 1839

Family Alveolinidae Ehrenberg, 1839 Ovalveolina Reichel 1936

Type species: Alveolina ovum d'Orbigny, 1850
Ovalveolina maccagnoae De Castro, 1966

(Figures 11e to $11 \mathrm{~h}$ )

Ovalveolina maccagnoae De Castro, 1966; Schroeder and Neumann, 1985, p. 106-109, pl. 50, figs. 5-7. Description: The test of megalospheric form is planispiral involute, spherical proloculus followed by a flexostyle; the chambers short and numerous; in equatorial section the chamberlets can be elongated, elliptical from the first whorls, later appearing rectangular, preseptal passage elongated occupies a third part of the chamber; in the subaxial section the chamberlets have a pyriform appearance in the last whorl; wall porcelaneous.

Remarks: The mid-Cretaceous alveolinids are poorly known from the New World but Streptalveolina mexicana Fourcade, Tardy and Vila (1974) was described from the Mexican Cenomanian strata (Aurora Formation). This species is considered endemic to the Caribbean Province, but appears to be related to species in the Mediterranean area such as S. peybernesi (De Castro, 1983). Streptalveolina mexicana has been also recorded in some localities of Gulf Coast in the Albian-Cenomanian (Scott, 2002; Mancini and Scott, 2006). Omaña et al. (2012) reported Ovalveolina maccagnoae De Castro, 1966 from the Cenomanian deposits of the Manantlan Range in Colima State, Mexico.

Further alveolinids Sellialveolina sp. and S. cf. drorimensis were reported from the Cenomanian in northern Peru by Jaillard and Arnaud-Vanneau (1993, p. 603).

Occurrence: VSLPP in the La Minita outcrop.

Family Peneroplidae Schultze, 1854

Peneroplis de Montfort, 1808

Type species: Peneroplis planatus Fichtel and Moll, 1798, p. 91

Peneroplis parvus De Castro, 1965

(Figure 11c)

Peneroplis parvus De Castro, 1965, p. 345-348, pl. 1, 14-15; Schroeder and Neumann, 1985, p. 86, pl. 39, figs. 1-17; Tasli et al., 2006, p.529, pl. 6, fig. O. Description: Test with a rounded proloculus, early stage planispirally coiled, later with or 
without uncoiling stage; the chambers quickly increasing in width, resulting in a flaring peneropliform test. Sutures slightly depressed. Wall is calcareous imperforate porcelaneous; the surface with numerous grooves alternating with fine ribs perpendicular to the sutures.

Remarks: Peneroplis parvus is like the Recent P. planatus but differs by having a smaller size and more numerous chambers. It differs from $P$. turonicus (Said and Kenawy, 1957) because the latter species lacks radial striae on the outside surface. By this character P. turonicus could be assigned to Laevipeneroplis, according to the foraminiferal generic classification of Loeblich and Tappan (1988).

Peneroplis was placed in the family Soritidae by Schroeder and Neumann (1985); later Loeblich and Tappan (1988) settled it in the family Peneroplidae because this form has chambers with a simple interior, while the family Soritidae has chambers subdivided by interseptal pillars or septula.

Occurrence: Peneroplis parvus was described for the first time by De Castro (1966) from the mid-Cenomanian from the Campania region (Italy); this species has been recorded from Spain (Calonge and Caus, 1996), Croatia (Velić and Vlahović, 1994), Turkey (Tasli, 2006), and Syria (Ghanem and Kuss, 2013).

VSLPP in the Llanos del Carmen, Cerritos, Guadalcazar, and Temazcal sections.

\section{Subclass Globothalamea Pawlowski, Holzmann} and Tyszka 2013

Order Rotaliina Delage and Hérouard, 1896

Superfamily Planorbulinacea Schwager, 1877

Family Cymbaloporidae Cushman, 1927 Archaecyclus Silvestri. 1908

Type species: Planorbulina cenomaniana Seguenza, 1882

Archaecyclus Silvestri, 1908, p. 134

Archaecyclus sp.

(Figure 11d)

Test large, convex planispirally coiled, five chambers in the first whorls, later forming an annular arrangement; the sutures are oblique, the wall calcareous, perforated, having a dark thin layer in middle position. The aperture is interiomarginal in the early stage; after with stolon-like openings at the lateral margins of each chamber (Loeblich and Tappan, 1988).

Occurrence: Archaecyclus sp. has been recorded by Jaillard and Arnaud-Vanneau (1993) from Peru.

VSLPP has been only observed in the Llanos del Carmen section.

\section{Conclusions}

The deposits of the upper part of the El Abra Formation preserved a rich and diverse association mostly composed of larger benthic foraminifera, which are described and illustrated for the studied succession. The species of benthic foraminifera have a significant age-diagnostic value in the El Abra shallow-water deposits, dating the succession studied here as mid-late Cenomanian.

The foraminiferal and algal assemblages are age-equivalent to the Mediterranean associations. Two zones are proposed for the sections from the El Abra Formation: the Pseudolituonella reicheli Assemblage Zone and the Nezzazatinella picardi Interval Zone.

The Pseudolituonella reicheli Assemblage Zone contains a rich and varied benthic foraminiferal association which was reduced to a few foraminifers that survived. The Nezzazatinella picardi Interval Zone later also disappeared when the hemipelagic Soyatal deposit took place (Whiteinella archaeocretacea Partial Range Zone) due to the large scale flooding and climate perturbations.

The integration of the data provided by the benthic foraminiferal association and the lithology enable a more reliable paleoenvironmental interpretation.

We consider that there was a first episode (midlate Cenomanian) in the Taninul facies of the El Abra Formation consisting of a warm shallow-water carbonate platform with open circulation and medium-high hydrodynamic energy. The ma 
ximum diversity of benthic foraminiferal assemblages coincides with this environment. Later, a decrease of benthic foraminiferal species diversity is recorded, with a few foraminiferal species surviving (Nezzazatinella picardi, miliolids, rotalids, and textularids) in association with algae. This change could be related to increasing nutrient availability in mesotrophic conditions.

The drowning event of the platform with a hemipelagic deposit (Soyatal Formation) occurred in the latest Cenomanian. It is marked by the bloom of pithonellids and $r$ and $r-k$ strategist planktic foraminifera and benthics such as gavellinellids, which are present in a deeper and eutrophic environment.

An environment with restricted circulation from the $\mathrm{El}$ Abra facies is distinguished by a shallow-water association of reduced diversity but commonly with numerous individuals of typical miliolid foraminifera. Another intermediate semi-restricted environment with a greater variety of foraminifera is also defined.

The foraminiferal and algae community have a marked Tethysian affinity.

\section{Acknowledgments}

This work was supported by DGAPA-PAPIIT IN1 19208 Project grants. We are greatly indebted to Dr. Rafael Barboza Gudiño (Director of the Geology Institute of the Universidad Autónoma de San Luis Potosí) for providing logistical field assistance. We are very grateful to Drs. Robert W. Scott (Precision Stratigraphy Associates and Tulsa University) and Ioan I. Bucur (Babeş-Bolyai Universit) for valuable and careful comments and suggestions that much improved the manuscript, and Dr. Esmeralda Caus (Universidad Autonoma de Barcelona) for the observations on the text.

The authors gratefully acknowledge Dr. Francisco Vega Vera (UNAM Mexico) for his precise editorial handling. We thank Joaquín Aparicio for preparing numerous thin sections.

\section{References}

Adkins, W.S., 1930, New rudists from the Texas and Mexican Cretaceous: University of Texas Bulletin, 3001, 77-100.

Afghah, M., Yousefzadeh, A., Shirdel, S., 2014, Biostratigraphic revision of Middle Cretaceous succession in south Zagros basin (SW of Iran): Journal of Earth Science \& Climate Change, 5 (8), 1-10. https://doi. org/10.4172/2157-7617.1000216

Aguayo, C.E., 1998, The middle Cretaceous El Abra limestone at its type locality (facies, diagenesis and oil emplacement): Revista Mexicana de Ciencias Geológicas, 15, 1-8.

Aguilera-Franco, N., 2003, Cenomanian/ Coniacian zonation (foraminifers and calcareous algae): Revista Mexicana de Ciencias Geológicas, 20 (3), 202-222.

Aguilera-Franco, N., Allison, P., 2005, Events of the Cenomanian/Turonian succession, southern Mexico: Journal of Iberian Geology, 31, 25-50.

Aguilera-Franco, N., Hernández Romano, U., Allison, P., 2001, Biostratigraphy and environmental changes across the Cenomanian and Turonian boundary, southern Mexico: Journal of South American Earth Sciences, 14, 237-255. https://doi. org/10.1016/s0895-9811(01)00014-1

Alencáster, G., 1998, New Caprinidrudist genera Guzzyella and Muellerriedia (Bivalvia Hippuritacea) from the Albian (Cretaceous) of Central Mexico: Revista Mexicana de Ciencias Geológicas, 15, 91-105.

Alencáster, G., García-Barrera, P., 2008, Albian Radiolitid (Mollusca-Bivalvia) from East-Central Mexico: Geobios 41(5), 571-587. https://doi.org/10.1016/j. geobios.2008.04.001

Anan, T. I., El Shahat, A., Genedi, A., Grammer, M., 2013, Depositional environment and sequence architecture of the Raha and $\mathrm{Abu}$ Qada Formations (Cenomanian/Turonian) 
west central Sinai: Journal of African Earth Sciences, 82, 54-69. https://doi. org/10.1016/j.jafrearsci.2013.02.008

Arnaud-Vanneau, A., Premoli-Silva, I., 1995, Biostratigraphy and systematic description of benthic foraminifers from mid-Cretaceous shallow-water carbonate platform sediments at sites 878 and 879 (Mit and Takuyo-Daisan Guyots), in: Haggerty, J.A., Premoli Silva, I., Rack, F., Nutt, M.K. (eds.) Texas, College Station, Proceedings of the Ocean Drilling Program, Scientific Results 144, 199-219.

Arnaud-Vanneau, A., Sliter, W.V., 1995, Early Cretaceous shallow-water benthic foraminifers and fecal pellets from Leg 143 compared with coeval faunas from the Pacific basin, Central America and the Tethys, in: Winterer, E.E., Sager, W.W., Firth, J.V., Sinton, J.M. (eds.) Texas, College Station, Proceedings of the Ocean Drilling Program, Scientific Program, 144, 199-219.

Barroso, B. F., 2004, Acanthoceratidae y zonación de amonites del Cenomaniense superior y del Turoniense inferior en el área Puentedey, Cuenca Vasco-Cantábrica: Coloquios de Paleontología, 54, 83-114.

Basáñez, L. M., Fernández-Turner, R., Rosales, D. C., 1993, Cretaceous Platform of VallesSan Luis Potosi, Northeast central Mexico, in: Simó, J. A., Scott, R. W., Masse, J. P. (eds.), Cretaceous Carbonate Platforms, Tulsa, Oklahoma: American Association of Petroleum Geologists Memoir, 56, 51-59.

Bernaus, J., Masse, P., 2006, Carinoconus iraquiensis (Foraminifera) a new orbitolinid from the Cenomanian Mishrif Formation of the oil fields of southeastern Iraq: Micropaleontology, 52 (5), 471-476. https:/ / doi.org/10.2113/gsmicropal.52.5.471

Berthou, P-Y., 1984a, Albian/Turonian stage boundaries and subdivisions in the western Portuguese Basin, with special emphasis on the Cenomanian/Turonian boundary in the ammonite facies and rudists facies: Bulletin of the Geological Society of Denmark, 33, 41-55

Berthou, P-Y., 1984b, Répartition stratigraphique actualisée des principaux foraminiféres benthiques du Crétacé Moyen et Supérieur du Bassin occidental portugais, Benthos 83, 2nd International Symposium on Benthic Foraminifera, Pau (1983), Elf Aquitaine Esso REP and Total CFP Pau and Bordeaux (1984), in Oertli, H. J. (ed.), 45-54.

Berthou, P-Y., Bengston, P., 2007, Stratigraphic correlation by microfacies of the Cenomanian/Conacian of the Sergipe Basin, Brasil: Lethaia, 22 (3), 246.

Berthou, P-Y., Lauverjat, J., 1979, Essai de synthèse paléogéographique et paléobiostratigraphique du bassin occcidental portugais au cours du Cretacé Supérieur: Giências da Terra UNL, 5, 121-144.

Bignot, G., Poisson, A., 1974, Le Cénomanien du flanc oriental du Katran Dağ (Sam Dağ) près d'Antalya (Turquie): Mineral Research and Exploration Institute of Turkey (MTA) Bulletin, 82, 71-77.

Bilotte, M., 1984, Les grands foraminifères benthiques du Crétacé Supérieur Pyrénéen. Biostratigraphie. Réflexion sur corrélations mésogéennes, Benthos 83, 2nd International Symposium on Benthic Foraminifera, Pau (1983), Elf Aquitaine Esso REP and Total CFP Pau and Bordeaux (1984), in Oertli, H. J. (ed.), 61-67.

Bonet, F., 1956, Zonificación microfaunística de las Calizas Cretácicas del Este de México: Boletín de la Asociación Mexicana de Geólogos Petroleros, 8, 389-489.

BouDhager-Fadel, M., 2008, Evolution and geological significance of larger benthic foraminifera, in Wignall, P.B. (ed.), Developments in Palaeontology and Stratigraphy 21: Amsterdam, Elsevier, 515p. 
Bozorgnia, F., Banafti, S., 1964, Microfacies and microorganisms of Paleozoic through Tertiary sediments of some parts of Iran: Teheran, National Iranian Oil Co., 1-22.

Calonge, A., Caus, E., 1996, Particularidades de los macroforaminíferos del Cenomaniense de la Cordillera Ibérica: implicaciones paleobiogeográficas: Geogaceta 20, 1191-194.

Carrillo-Bravo, J., 1971, La Plataforma VallesSan Luis Potosí: Boletín de la Asociación Mexicana de Geólogos Petroleros, 23, 1-102. Caus, E., Teixell, A., Bernaus, J.B., 1997, Depositional model of Cenomanian/ Turonian (Sopeira Basin, NE Spain): Interplay between tectonics, eustasy and biological productivity: Palaeogeography, Palaeoclimatology, Palaeoecology, 129, 23-36. https://doi.org/10.1016/ s0031-0182(96)00051-x

Caus, E., Bernaus, J.M., Calonge, E., MartinChivelet, J., 2009, Mid-Cenomanian separation of Atlantic and Tethyan domains in Iberia by land-bridge: The origin of the larger foraminifera provinces?: Palaeogeography, Palaeoclimatology, Palaeoecology, 283, 172-181.

Checconi, A., Rettori, R., Spalluto, L., 2008, Biostratigrafia a foraminiferi del Cretaceo Superiore della successione di Parco Priori (Calcare de Altamura, Piattaforma Apula, Italia meridionale): Annali dell'Universita Ferrara Museologia Scientifici et Naturalistica, 8, 1-9.

Cherchi, A., Schroeder, R., 1990, Dicyclina sampoi n. sp., a larger foraminifer from Cenomanian of Zagros Range (SW Iran): Paläontologische Zeitschrift, 64 (3-4), 203-211. https://doi. org/10.1007/bf02985714

Chiocchini, M., 2008, New benthic foraminifers (Miliolacea and Soritacea) from Cenomanian and Upper Turonian of the Monte Cairo (southern Latium, Central Italy): Memorie Descrittive della Carta Geologica d'Italia, 84, 171-202.
Chiocchini, M., Mancinelli, A., Molinari-Paganelli, V., Tilia-Zuccari, A., 1979, Dasycladales and Codiaceae algae stratigraphic distribution in the carbonate platform: Mesozoic sequence of central-southern Lazio (Italy): Bulletin des Centres de Recherches ExplorationProduction, 3, 525-535.

Chiocchini, M., Mancinelli, A., Romano, A., 1984, Stratigraphic distribution of benthic foraminifera in the Aptian, Albian, and Cenomanian carbonate sequences of the Aurunci and Ausoni Mountains (southern Lazio, Italy), Benthos 83, 2nd International Symposium on Benthic Foraminifera, Pau (1983), Elf Aquitaine Esso REP and Total CFP Pau and Bordeaux (1984), in Oertli, H.J. (ed.), 167-181.

Conkin, J.E., Conkin, B.M., 1958, Revision of the genus Nummoloculina heimi Bonet: Micropaleontology, 4 (2), 149-158. https:// doi.org/10.2307/1484300

Coogan, A. H., 1973, Nuevos rudistas del Albiano y Cenomaniano de México y Sur de Texas: Revista del Instituto Mexicano del Petróleo, 5, 51-83.

Cserna, E., Bello-Barradas A., 1963, Geología de la Sierra de Álvarez, Municipio de Zaragoza, San Luis Potosí: Instituto de Geología UNAM Boletín, 71, 23-63.

Cushman, J.A., Applin, E.R., 1947, Two new species of Lower Cretaceous foraminifera from Florida: Contributions from the Gushman Laboratory for Foraminiferal Research, 23 (291), 29-30.

Cuvillier J., Szakall, V., 1949, Foraminifères d'Aquitaine. Première partie (Reophacidae à Nonionidae): Toulouse, F. Boisseau Édit., $112 \mathrm{p}$.

Dalbiez, F., 1958, Cuneolina hensoni a new lowermost Cretaceous marker in southwestern France: Micropaleontology, 4 (1), 97-101. https:// doi.org/10.2307/1484256

De Castro, P., 1965, Su alcune Soritidae (Foraminiferida) del Cretacico della Campania: Bolletino Della Società Naturalisti in Napoli, 74, 317-372. 
De Castro, P., 1966, Contributo alla conoscenza delle alveoline Albiano/Cenomaniane della Campania: Bolletino Della Società Naturalisti in Napoli, 75, 219-275.

De Castro, P., 1983, Obsevazioni paleontologiche, in De Castro, P., Peybernès, B. (eds.), Un nuovo Alveolinidae dell'Albiano di Spagna: Atti dell' Accademia Pontaniana Napoli, n.s, t. 31 (1982), 7-32.

Decrouez, D. 1977, Le Crétacé d'Argolide (Péloponnèse septentrional, Grèce): remarques micropaléontologiques: Notes du Laboratoire de Paléontologie de l'Université de Genève, 1 (1), 8 p.

Decrouez, D. Radoičić, R., 1977, Nummoloculina irregularis n. sp., nouveau Foraminifère du Sénonien (Santonien) de la Serbie occidentale (Dinarides yougoslaves): Notes Lab. Paléont. Univ. Genève, 7, 1-3

Dozet, S., Šribar, L., 1998, Lower Cretaceous shallow marine sedimentation and biota on Dinaric Carbonate Platform between Logatec, Krka and Kolpa (southeastern Slovenia): Geologija, 40, 153-185. https:// doi.org/10.5474/geologija.1997.007

Drzewiecki, P.A., Simó, J.A., 1977, Carbonate platform drowning and oceanic events on a mid-Cretaceous carbonate platform, south-central Pyrenees, Spain: Journal of Sedimentary Research, 67, 698-714. https://doi.org/10.1306/ d426861c-2b26-11d7-8648000102c1865d

Dozet, S., Šribar, L., 1998, Lower Cretaceous shallow marine sedimentation aand biota on Dinaric Carbonate Platform between Logatec, Krka and Kolpa (southeastern Slovenia): Geologija, 40, 153-185. https:// doi.org/10.5474/geologija.1997.007

El-Sabbagh, A., Tantawy, A.A., Keller, G., Khozyem, H., Spangenberg, J., Adatte, T., Gersth, B., 2011, Stratigraphy of the Cenomanian/Turonian Oceanic Anoxic Event in shallow shelf sequences: Cretaceous Research, 32 (6), 705-722. https://doi. org/10.1016/j.cretres.2011.04.006
Enos, P., Stephens, B. P., 1993, Mid-Cretaceous basin margin carbonates, east central Mexico: Sedimentology, 40, 539-556. https://doi. org/10.1111/j.1365-3091.1993.tb01349.x

Ettachfini, E.M., Andreu, B., 2004, Le Cenomanien et le Turonien de la Plate-forme Préafricaine du Maroc: Cretaceous Research, 25(2), 277-302. https://doi.org/10.1016/j. cretres.2004.01.001

Ettachfini, E.M., Souhel, A., Andreu, B., Caron, M., 2005, La limite Cénomanien/Turonien dans le Haute Atlas central Maroc: Geobios, 38, 57-68. https://doi.org/10.1016/j. geobios.2003.07.003

Farinacci, A., Yeniay, G., 1986, Biostratigraphy and event-analysis of the Cenomanian/ Maastrichtian carbonates of the Bey Daglari (western Taurus, Turkey): Paleopelagos, 4, 47-59.

Filkorn, H., Scott, R.W., 2011, Microfossils, paleoenvironments and biostratigraphy of the Mal Paso Formation (Cretaceous, upper Albian), State of Guerrero, Mexico: Revista Mexicana de Ciencias Geológicas, 28 (1), 175-191.

Fleury,J-J., 1980, Les zones du Gavrovo-Tripolitza et du Pinde-Olonos (Grèce continentale et Péloponnèse du Nord). Evolution d'une plate-forme et d'un bassin dans le cadre alpin: Publication de la Société Géologique du Nord, Villeneuve d'Asq 4, (1-2), 650 p.

Flügel, E., 2004, Microfacies of Carbonate Rocks. Analysis, Interpretation and Application: Germany, Springer, 976 pp.

Fourcade, E., Tardy, M., Vila, J.M., 1974, Streptalveolina mexicana n. gen. n. sp., un alveolinidae nouveau (Foraminifère) du Cénomanien du Mexique: Revue de Micropaléontologie, 17, 110-116.

Frijia, G., Parente, M., Di Lucia, M., Mutti, M., 2015, Carbon and strontium isotope stratigraphy of the Upper Cretaceous (Cenomanian/Campanian) shallowwater carbonates of southern Italy: Chronostratigraphic calibration of larger foraminifera biostratigraphy: Cretaceous Research, 53, 110-139. https://doi. org/10.1016/j.cretres.2014.11.002 
Gale, A.S., Voigt, S., Sageman, B.B., Kennedy, W.J., 2008, Eustatic sea-level record for the Cenomanian (Late Cretaceous) Extension to the Western Interior Basin, USA: Geology, 36, 859-862. https://doi.org/10.1130/ g24838a.1

Gebhardt, T.H., Friedrich, O., Schenk, B., Fox, L., Hart, M., Wagreich, M., 2010, Paleoceanographic changes at the northern Tethyan margin during the Cenomanian/Turonian Oceanic Anoxic Event (OAE-2): Marine Micropaleontology, 77, 25-45. https://doi.org/10.1016/j. marmicro.2010.07.002

Gendrot, G., 1963, Quelques foraminifères nouveaux du Sénonien inférieur des Martigues (Bouches du Rhone): Revue de Micropaléontologie, 6, 67-72.

Gendrot, G., 1968, Stratigraphie et micropaléontologie de Sénonien de la région des Martigues près Marseille (Bouches du Rhône): Eclogae Geologicae Helvetiae, 61 (2), 674-675.

Ghanem, H., Kuss, J., 2013, Stratigraphic control of the Aptian-early Turonian sequences of the Levant, coastal range northwest Syria: GeoArabia, 18 (4), 85-132.

Ghanem, H., Mouty, M., Kuss, J., 2012, Biostratigraphy and carbon-isotope stratigraphy of the uppermost Aptian to upper Cenomanian strata of the south Palmyrides, Syria: GeoArabia, 17, (2), 155-184.

Gräfe, K-U., 2005, Late Cretaceous benthic foraminifers from the Basque-Cantabrian Basin, northern Spain: Journal of Iberian Geology, 31 (2), 277-298.

Hallam, A., 1992. Phanerozoic sea level changes, New York, Columbia University Press, , 266p.

Hallock, P., Glenn, E.C., 1986, Larger foraminifera: a tool for paleoenvironmental analysis of Cenozoic carbonate deposicional facies: Palaios, 1, 55-64. https://doi. org/10.2307/3514459
Hamaoui, M., 1965, Biostratigraphy of Cenomanian Type Hazera Formation: Geological Survey of Israel, Jerusalem, Stratigraphy Sector 2b, 1-27.

Hamaoui, M., 1966, Microfossils from the Cenomanian sections in Negev: Geological Survey of Israel, Jerusalem, Rep. no. Pal., 3/66. Sect 2b, 1-12.

Hamaoui, M., Saint-Marc, P, 1970, Microfaunes et microfaciès du Cénomanien du ProcheOrient: Bulletin du Centre de Recherches Pau-SNPA, 4, 257-352.

Haq, B.U., 2014, Cretaceous eustasy revisited: Global and Planetary Change, 113, 44-58. https://doi.org/10.1016/j. gloplacha.2013.12.007

Haq, B.U., Hardenbol, J., Vail, P.R., 1987, Chronology of fluctuating sea levels since the Triassic: Science, 235, 1156-116. https:// doi.org/10.1126/science.235.4793.1156

Hart, M.B., Callapez, P.M., Fisher, J.K., Hannant, T. K., Montero, J.F., Price, G.D., Watkinson, M.P., 2005, Micropaleontology and Stratigraphy of the Cenomanian/Turonian boundary in the Lusitain Basin, Portugal: Journal of Iberian Geology, 31 (2), 311-326.

Haynes, J., 1965, Symbiosis, wall structure and habitat in foraminifera: Contributions from the Cushman Foundation for Foraminiferal Research, 16, 40-43.

Henson, F.R.S., 1948a, New Trochamminidae and Verneuilidae from Middle East: Annals and Magazine of Natural History, 2 (14), 605-630.

Henson, F. R. S., 1948b, Larger imperforate foraminifera of southwestern Asia, families Lituolidae, Orbitolinidae and Meandropsinidae: London, British Museum of the Natural History, , $127 \mathrm{p}$.

Hohenegger, J., 2000, Coenoclines of larger foraminifera: Micropaleontology, 46, Supl. 1, 127-151.

Hohenegger, J., 2004, Depth Coenoclines and environmental considerations of Western Pacific Larger Foraminifera: Journal of Foraminiferal Research, 34, 9-33. https:// doi.org/10.2113/0340009 
Husinec, A., Velić, I.,Fućek, L., Vlahović, I., Maticeč, D., Oštrić, N.,Korbar, T., 2000, mid-Cretaceous orbitolinid (Foraminiferida) record from the islands of Cres and Lošinj (Croatia) and its regional stratigraphic correlation: Cretaceous Research, 21(1), 155-171. https://doi.org/10.1006/ cres.2000.0203

Husinec, A., Velić, I.,Sokac, B., 2009, Diversity patterns in mid-Cretaceous foraminifers and Dasycladacean algae, in Demchuk, T.D., Gary, A.C. (eds.), Geological problem solving with microfossils: a volume in honor of Garry D. Jones: SEPM Special Publication, 93, 154-170.

Ismail, A.A., Hussein-Kamel, Y.F., Boukhary, M., Ghandour, A.A., 2009, Late Cenomanian/ early Turonian foraminifera from Eastern Desert Egypt: Micropaleontology, 55 (4), 396-412.

Jaillard, E., Arnaud-Vanneau, A., 1993, The Cenomanian/Turonian transition of the Peruvian margin: Cretaceous Research, 14, 585-605. https://doi.org/10.1006/ cres. 1993.1041

Kaminski, M.A., 2014, The year 2010 classification of the agglutinated foraminifera: Micropaleontology, 61 (1), 89-108.

Koch, R., Buser, S., Bucur, I.I., 1998, Biostratigraphy and facies development of mid-to Late Cretaceous strata from the Nanos Mountain (Western Slovenia High karst): Zentralblatt für Geologie und Palaeontologie, (1996), Heft 11-12, 1195-1215.

Korbar, T., Glumac, B., Gvetko Te Šović, B., Cadieux, S.H., 2012, Response of a carbonate platform to the Cenomanian/ Turonian drowning and OAE 2: a case study from Adriatic Platform (Dalmatia, Croatia): Journal of Sedimentary Research, 82(3G), 163-176. https://doi.org/10.2110/ jsr.2012/17

Labarthe-Hernández, G., Tristán-González, M., Aranda-Gómez, J. J., 1982, Revisión estratigráfica del Cenozoico de la parte central del Estado de San Luis Potosí:
Universidad Autónoma de San Luis Potosí, Instituto de Geología y Metalurgia, Folleto Técnico, 85, 205 p.

Langer,M.R., 1993,Epiphytic foraminifera: Marine Micropaleontology, 20, 235-265. https:// doi.org/10.1016/0377-8398(93)90035-v

Laug, B., Peybernès, B., 1979, Daxia minima nov. sp., Lituolide de l'Aptien Basco-Béarnais: Geobios, 12 (5), 717-723. https://doi. org/10.1016/s0016-6995(79)80098-4

Lézin, C., Andreu, B., Ettachfini, E. M., Wallez, M-J., Lebedel, V., Meister, Ch., 2012, The upper Cenomanian/lower Turonian of the Peafrican trough Morocco: Sedimentary Geology, 245-246, 1-16. https://doi. org/10.1016/j.sedgeo.2011.12.003

Loeblich, A.R., Tappan, H., 1988, Foraminiferal genera and their classification. New York, Van Nostrand Reinhold Co., 970 p.

López-Doncel, R., 2003, La Formación Tamabra del Cretácico medio en la porción central del margen occidental de la Plataforma VallesSan Luis Potosí, centro-noreste de México: Revista Mexicana de Ciencias Geológicas, 20, 1-19.

Luperto-Sinni, E., 1966, Microfauna del Cretaceo delle Murge Baresi: Geologica Romana, 5, 117-156.

Luperto-Sinni, E., Masse, J. P., 1993, Specie nuove di Foraminiferi bentonici dell'Aptiano inferiore carbonatico delle Murge (Italia Meridionale): Rivista Italiana di Paleontologia e Stratigrafia, 99 (2), 215-216.

Mancinelli, A., Chiocchini, M., 2006, Cretaceous benthic foraminifers and calcareous algae from Monte Cairo (southern Latium, Italy): Bolletino della Società Paleontologica Italiana, 45 (1), 91-113.

Mancini, E.A., Scott. R.W., 2006, Sequence Stratigraphy of Comanchean Cretaceous Outcrop Strata of Northeast and SouthCentral Texas: Implications for Enhanced Petroleum Exploration: Transactions Gulf Coast Association of Geological Societies, 56, 539-550. 
Marie, P., 1954, Quelques genres nouveaux de Foraminifères du Crétacé à facies récifal: Compte Rendu 19th International Geological Congress, Alger, 1952, sect 13, 15, 117-124.

Maync, W., 1952, Critical taxonomy study and nomenclatural revision of the Lituolidae based upon the prototype of the family, Lituola nautiloidea Lamarck, 1804: Contributions from the Cushman Foundation for Foraminiferal Research, 3 (2), 35-56.

Maync, W., 1953, Hemicyclammina sigali n. gen n. sp from the Cenomanian of Algeria: Contributions from the Cushman Foundation for Foraminiferal Research, 5, 148-150.

Michaud, F., 1987, Stratigraphie et paléogeographie du Mesozoique du Chiapas (Sud Est du Mexique. Académie de Paris Université Pierre et Marie Curie, Paris: Mémoires de Sciences de la Terre, 87, 298 p. Miller, K.G., Kominz, M.A., Browning, J.V., Wright, J.D., Mountain, G.S., Katz, M.E., Sugarman, P.J., Cramer, B.S., Christie-Blick, N., Pekar, S.F., 2005, The Phanerozoic Record of Global-Sea Level Change: Science, 310, 5752, 1293-1298. https://doi.org/10.1126/ science.1116412

Moreau, P., 1996, Analyse de la transgression cenomanienne du Basin de l'Aquitaine: Géologie de la France, 1, 3-16.

Moro, A., Jelaska, J., 1994, Upper Cretaceous peritidal deposits of Olib and Ist Islands (Adriatic Sea, Croatia): Geologica Croatica, 47 (1), 53-65.

Mouty, M.A., Al Maleh, A.K.H., Abou Laban, H., 2003, Le Crétacé moyen la chaîne des Palmyrides (Syrie centrale): Geodiversitas, 25, 429-443.

Munier-Chalmas, E.,1887, Sur la Cyclolina et trois nouveaux genres de foraminifères de couches à Rudistes. Cyclopsina, Dicyclina et Spirocyclina: Compte Rendus des Séances de la Société Géologique de France,4 (7), 30-31.

Murray, J.W., 1991, Ecology and Paleoecology of Benthic Foraminifera: Harlow Logman Scientific \& Technical, London, 298-301.
Murray, J.W., 2006, Ecology and Applications of Benthic Foraminifera: Cambridge University Press, Cambridge, 426 p. https://doi. org/10.1017/CBO9780511535529

Neagu, T., 1979, Doneés nouvelles concernant les représentants de la famille des Pfenderinidae del'Éocretacé de la Dobrogea méridionale (Roumanie): Revista Española de Micropaleontología, 11 (3), 474-504.

Neumann, M., 1962, A propos de la stratigraphie de l'Île Madame: Compte Rendu Sommaire des Séances de la Société Géologique de France, 3, 93-95.

Neumann, M., 1965, Contribution à l'étude de quelques Lituolidés du Cénomanien de l'Île Madame (Charente Maritime): Revue de Micropaléontologie, 8 (2), 90-95.

Omaña, L., Centeno-García, E., Buitrón-Sánchez, B.E., 2012, Comunidades bentónicas de plataforma del Cretácico asociadas a arcos magmáticos en la parte occidental de México: Paleontología Mexicana, 62, 121-132.

Omaña, L., López-Doncel, R., Torres-Hernández, J.R., Alencáster, G., 2012, Biostratigraphy and paleoenvironment of the Cenomanian/ Turonian boundary interval based on foraminifera from W Valles-San Luis Potosí Platform, Mexico: Micropaleontology, 58 (6), 457-485.

Omaña, L., Alencáster, G., Buitrón, B.E., 2016, Mid-early late Albian foraminiferal assemblage from the El Abra Formation in the El Madroño locality, eastern Valles-San Luis Potosí Platform, Mexico: Paleoenvironmental and paleobiogeographical significance: Boletín de la Sociedad Geológica Mexicana, 68, 477-496. https://doi.org/10.18268/ bsgm2016v68n3a6

Omara, S., 1956, New foraminifera from the Cenomanian of Sinai, Egypt: Journal of Paleontology, 30, 883-890.

Omara, S., Strauch, F., 1965, The foraminiferal genus Nezzazata Omara: Rivista Italiana di Paleontolgia e Stratigrafia, 71, 547-562. 
Ornelas, M., 1984, Estudio bioestratigráfico del Cretácico en el Prospecto Aguililla-Ciudad Guzmán: Instituto Mexicano del Petróleo, Unpublished Report, No. C-1 146, 1-50.

Parente, M., Frijia, G., Di Lucia, M., Jenkyns, H. G., Woodfine, R. G., Baroncini, F., 2008, Stepwise extinction of larger foraminifers at the Cenomanian/Turonian: A shallowwater perspective on nutrient fluctuations during Oceanic Anoxic Event 2 (Bonarelli Event): Geology, 36 (9), 715-718. https:// doi.org/10.1130/g24893a.1

Pawlowski,J., Holzmann, M., Tyszka, J., 2013, New supraordinal classification of Foraminifera: Molecules meet morphology: Marine Micropaleontology, 100, 1-10. https://doi. org/10.1016/j.marmicro.2013.04.002

Philip, J., Airaud-Crumière, C., 1991, The demise of the rudist-bearing carbonate platform at the Cenomanian/Turonian boundary: a global control: Coral Reefs, 10 (2), 115-125. https://doi.org/10.1007/bf00571829

Philip, J., Borgomano, J., Al-Maskiry, S., 1995, Cenomanian-early Turonian carbonate platform of northern Oman stratigraphy and paleoenvironments: Palaeogeography, Palaeoclimatology, Palaeoecology, 119, 77-92. https://doi. org/10.1016/0031-0182(95)00061-5

Polavder, S., 2003, Upper Cretaceous integrated biostratigraphy in the western belt of the Vardar Zone: Geologia Carphatica, 54 (2), 81-91.

Ponce de León, A., 1983, Estudio bioestratigráfico del Cretácico en el Prospecto-TepalcatepecAlberca-Madrid (Cuenca Jalisco-Colima): Instituto Mexicano del Petróleo, Unpublished Report, No. C-1 129, 1-35

Rahimpour-Bonab, H., Mehrabi, H., EnayatiBigdoli, A.H., Omdivar, M., 2012, Coupled imprints of climate and recurring emergence on reservoir evolution of a mid-Cretaceous carbonate ramp, Zagros Basin, southwestIran: Cretaceous Research, 37, 15-34. https:// doi.org/10.1016/j.cretres.2012.02.012
Reichel, M., 1936, Étude sur les Alvéolines: Mémoires Société Paléontologique Suisse, $57,1-47$.

Reiss, Z., 1957, Occurrence of Nezzazata in Israel: Micropaleontology, 3 (3), 259-262. https:// doi.org/10.2307/1484111

Reiss, Z., 1961, Lower Cretaceous microfacies and microfossils from Galilee: Bulletin of the Research Council of Israel Geosciences 10G (14), 223-246.

Robertson, A.H.F., Parlak, O., Metin., Y., Vergili, Ö., Tasli, K., Inan, N., Soycan, H., 2013, Late Paleozoic/Cenozoic tectonic development of carbonate platform, margin and oceanic units in the Eastern Taurides, in Robertson, A.F.H., Parlak, O., Ünlügenç, U.C. (eds.), Geological Development of Anatolia and the easternmost Mediterranean region: Geological Society London, Special Publication 372, 167-218

Said, P., Kenawy, A., 1957, Foraminifera from Turonian rocks of Abu-Raash, Egypt: Cushman Foundation for Foraminiferal Research Contributions, 8, 77-86.

Saint-Marc, P., 1966, Étude micropaléontologique de l'Albien, du Cénomanien et du Turonien d'Audignon (Landes): Bulletin de la Société Géologique de France, 7 (8), 663-666.

Saint-Marc, P., 1974, Études stratigraphique et micropaléontologique de l'Albien, du Cénomanien et du Turonien du Liban: Notes Mémoires du Moyen Orient, Paris-Beirut, $342 \mathrm{p}$.

Salvador, A., 1991, Origin and development of the Gulf of Mexico basin, in Salvador, A. (ed.), The Gulf of Mexico Basin: The Geology of North America, Austin, Texas, 389-444. https://doi.org/10.1130/ DNAG-GNA-J.389

Sampó, M., 1969, Microfacies and microfossils of the Zagros area Southwestern Iran (from pre-Permian to Miocene), International Sedimentary Petrography, Leiden, H.J Brill, Michigan, 108 p. 
Sari, B., Tasli, K., Özer, S., 2009, Benthonic foraminiferal biostratigraphy of the Upper Cretaceous (middle Cenomanian/ Coniacian) sequences of the Bey Daĝlari carbonate platform: Turkish Journal of Earth Sciences, 18, 393-345.

Sartoni, M., Crescenti, U., 1962, Ricerche biostratigrafiche nel Mesozoico dell' Appennino meridionale: Giornale di Geologia, 29, 161-302.

Schlager, W., 1981, The paradox of drowned reefs and carbonate platforms: Geological Society of America Bulletin, 92 (4), 197211. https://doi.org/10.1130/0016$7606(1981) 92<197:$ tp odra $>2.0$. co;2

Schlumberger, G., 1899, Note sur quelques foraminifères nouveaux ou peu connus du Crétacé d'Espagne: Bulletin de la Société Géologique de France, (3e Série), t. XXVII, 456-465.

Schlumberger, G., Choffat, P., 1904, Note sur le genre Spirocyclina Munier-Chalmas et quelques autres genres du même auteur: Bulletin Société Géologique de France, (4e Série), t. IV (3), 358-368.

Schroeder, R., Neumann, M., 1986, Les grands foraminifères du Crétacé moyen de la Région Méditerranéenne: Geobios Mémoire Spécial, 7, 1-161. https://doi.org/10.1016/ s0016-6995(86)80010-9

Schulze, F., Marzouk, A.M., Bessiouni, A.A., Kuss, J., 2004, The Late Albian/Turonian carbonate platform succession of west central Jordan: Stratigraphy and crises: Cretaceous Research, 25 (5), 709-737. https://doi. org/10.1016/j.cretres.2004.06.008

Scott, R.W., 1990, Models and Stratigraphy of mid-Cretaceous reef communities, Gulf of Mexico, in Lidz, B.H. (ed.), SEPM Concepts in Sedimentology and Paleontology, 2, 1-99.

Scott, R.W., 2002, Upper Albian Foraminifers new in west Texas: Journal of Foraminiferal Research, 32 (1), 43-50. https://doi. org/10.2113/0320043
Scott, R.W., Finch, R.C., 1999, Cretaceous carbonate, biostratigraphy and environments in Honduras, in Mann, P. (ed.), Caribbean Basins. Sedimentary Basins of the World 4: Amsterdam, Elsevier, 151-165.

Scott, R.W., González-León, G., 1991, Paleontology and biostratigraphy of Cretaceous rocks Lampazos area, Sonora, Mexico: Geological Society of America Special Paper, 254, 51-67. https://doi. org/10.1130/spe254-p51

Shirazi, M.P.N., 2009, Albian/Cenomanian zonation (foraminifers and calcareous algae) in the northern Fars, Iran: American Journal of Applied Sciences, 6 (4), 709-712. https:// doi.org/10.3844/ajas.2009.709.714

Shirazi, M.P.N., Bahrami, M., Rezaee, B., Gharamani, S., 201 1, Microbiostratigraphy of Kazhdumi Formation in the north western Shiraz (southwest Iran) on the basis of foraminifera and calcareous algae: Acta Geologica Sinica (English edition), 85 (4), 777-783. https://doi. org/10.1111/j.1755-6724.2011.00483.x

Simone, L., Bravi, S., Carannante, G., PomoniPapaioannou, F., 2012, Arid versus wet climatic evidence in the mid-Cretaceous calcareous successions of the southern Apenninos (Italy): Cretaceous Research, 36, 6-23. https://doi.org/10.1016/j. cretres.2012.01.005

Sohl, N.P., Martínez, E.,Salmerón-Ureña, P., Soto-Jaramillo, F., 1991, Upper Cretaceous, in Salvador, A. (ed.), The Gulf of Mexico Basin: Boulder: Geological Society of America, The Geology of North America, Austin, Texas, 205-544.

Spalluto, L., 2012, Facies evolution and sequence chronostratigraphy of "mid" Cretaceous shallow-water carbonate succession of Apulia Carbonate Platform from the northern Murge (Apulia, southern Italy): Facies, 58 (1), 17-36. https://doi.org/10.1007/ s10347-011-0266-0 
Suter, M., 1984, Cordilleran deformation along the eastern edge of the Valles-San Luis Potosí carbonate Platform, Sierra Madre Oriental fold thrust east-central Mexico: Geological Society of America Bulletin, 95, 1387-1397. https://doi.org/10.1130/0016$7606(1984) 95<1387: \mathrm{cd}$ a te e $>2.0$. co;2

Suter, M., 1987, Structural transverse across the Sierra Madre Oriental fold thrust east-central Mexico: Geological Society of America Bulletin, 98 (3), 249-264. https://doi. org/10.1130/0016-7606(1987)98<249:stats $\mathrm{m}>2.0 . \mathrm{co} ; 2$

Suter, M., 1990, GeologíadelaHoja Tamazunchale, Estados de Hidalgo, Querétaro y San Luis Potosí: Instituto de Geología, UNAM, Ciudad de México, México, 55 p.

Tasli, K, Özer, E., Koc, H., 2006, Benthic Foraminiferal assemblages of the Cretaceous platform carbonate succession in the Yavca area (Bolkar Mountains, S. Turkey): biostratigraphy and paleoenvironment: Geobios, 39(4), 521-533. https://doi. org/10.1016/j.geobios.2005.05.002

Tavitas, G.J., Solano M. B., 1984, Estudio bioestratigráfico del subsuelo en el oriente dela Plataforma Valles-San Luis Potosí, Memoria del Tercer Congreso Latinoamericano de Paleontología: Perrilliat, G. (ed.), Oaxtepec, México, 225-236.

Torres-Hernández, J.R., 1994, Evolución estructural de la Sierra de Guadalcazar, S.L.P.: Master's thesis, Facultad de Ciencias, UNAM, Ciudad de México, 77 p.

Tronchetti, G., Zijlstra-Bessais, H., 2002, Minouxia inflata nov. sp., nouveau foraminifère benthique du Cénomanien de Tunisia.
Réflexion sur les genres Minouxia Marie, 1954 et Tetraminouxia Gendrot, 1963: Revue de Paléobiologie, 21 (2), 539-551.

Ullastre, J., Masriera, A., 2006, El anticlinal de Bóixols-Muntanya de Nargó: consideraciones estratigráficas y estructurales basadas en una nueva cartografía geológica (Pirineo catalán, España): Treballs del Museu de Geologia de Barcelona, 14, 5-35.

Velić, I., Vlahović, I., 1994, Foraminiferal assemblages in the Cenomanian of BuzetSavudrija area (nortwestern Istria, Croatia): Geologia Croatica, 47 (1), 25-43.

Venegas-Rodríguez, G., Barboza-Gudiño, J.R., López-Doncel, R.A., 2009, Geocronología de circones detríticos en capas del Jurásico Superior de las áreas de Catorce y Alamitos en el estado de San Luis Potosí: Revista Mexicana de Ciencias Geológicas, 26 (2), 466-481.

Weidich, J.F., Al-Harithi, T., 1990, Agglutinated foraminiferafrom the Albian and Cenomanian of Jordan, in Hemleben, C., Kaminski, M.A., Kuhnt, W., Scott, D.B., (eds.) Paleoecology, Biostratigraphy, Paleoceanography and Taxonomy of Agglutinated Foraminifera. Tübingen, Springer Link, NatoAsi Series 327, 587-609.

Wilson, J.L., 1975, Carbonate Facies in Geologic History: Berlin, Springer, 471 p. https://doi. org/10.1007/978-1-4612-6383-8

Wilson, J.L., Ward, W.C., 1993, Early Cretaceous carbonate platforms of northeast and east central Mexico, in Simó, J. A., Scott, R. W., Masse, J. P. (eds.), Cretaceous Carbonate Platforms: American Association of Petroleum Geologists Memoir, 56, 35-49. 